\title{
A satellite ocean color observation operator system for eutrophication assessment in coastal waters
}

\author{
Andrew Clive Banks ${ }^{\mathrm{a}, *}$, Pascal Prunet ${ }^{\mathrm{b}}$, Julien Chimot ${ }^{\mathrm{b}}$, Pedro Pina ${ }^{\mathrm{c}}$, Jerome Donnadille ${ }^{\mathrm{b}}$, Eric Jeansou ${ }^{\mathrm{b}}$, \\ Muriel Lux ${ }^{\mathrm{b}}$, Giorgos Petihakis ${ }^{\mathrm{a}}$, Gerasimos Korres ${ }^{\mathrm{d}}$, Giorgos Triantafyllou ${ }^{\mathrm{d}}$, Clement Fontana ${ }^{\mathrm{e}}$, \\ Claude Estournel ${ }^{\mathrm{f}}$, Caroline Ulses ${ }^{\mathrm{f}}$, Luis Fernandez ${ }^{\mathrm{c}}$ \\ ${ }^{a}$ Institute of Oceanography, Hellenic Centre for Marine Research (HCMR), P.O. Box 2214, 71003 Heraklion, Crete, Greece \\ ${ }^{\mathrm{b}}$ Noveltis, Parc Technologique du Canal, 2 Avenue de l'Europe, 31520 Ramonville-Saint-Agne, France \\ c MARETEC, Instituto Superior Técnico (IST), Secção de Ambiente e Energia, Departamento de Mecânica, Universidade Técnica de Lisboa, Av. Rovisco Pais, 1049-001 Lisboa, Portugal \\ d Institute of Oceanography, Hellenic Centre for Marine Research (HCMR), P.O. Box 712, 19013 Anavissos, Attika, Greece \\ e Laboratoire d'Océanographie Physique et Biogéochimique (LOB), Centre National de la Recherche Scientifique (CNRS)/l'Université de la Méditerranée (UMR), 6535 Marseille, France \\ ${ }^{\mathrm{f}}$ Laboratoire d'Aérologie (LA), Observatoire Midi Pyrénées (OMP), 14 avenue Edouard Belin, 31400 Toulouse, France
}

During the INSEA project the potential positive role that remote sensing products can play in coastal eutrophica-tion assessment systems using assimilation into coupled hydrodynamic-biogeochemical models has been shown. However, products derived from satellite ocean color data continue to suffer from high levels of inaccu-racy when compared with in situ measurements of the surface layer of the ocean. This has been particularly pro-nounced for coastal waters and waters optically classified as Case-II. The early success of using empirical relationships between chlorophyll and simple band ratios to derive estimates of surface layer chlorophyll from the first ocean color satellite sensors' data (i.e. CZCS), has led mainstream ocean color remote sensing and stan-dard ocean color products towards following this approach for subsequent sensors (e.g. SeaWiFS and MODIS). Chlorophyll has continued to be the main focus product but is only related to one of the optical properties of sea water, namely the absorption of light by phytoplankton, whereas empirical band ratio approaches use wave-length banded water leaving radiance resultant from all absorption and scattering of light by all the optically ac-tive components of the ocean surface layer. We suggest that using approaches that do not fully exploit remote sensing optical data through a parameterization of the optical properties of sea water, is the main reason for the poor performance of many ocean color products when compared with in situ data. This is in concordance with the International Ocean Color Coordinating Group (IOCCG) and following their recent guidelines, novel in-herent optical properties approaches (e.g. for MERIS) and the lines of research that are being used in atmospheric remote sensing, we present a demonstration 'observation operator' system that is based on biogeochemical model output, optical properties (apparent and inherent), and radiative transfer modeling. In the forward mode we demonstrate the system by producing MODIS and SeaWiFS synthetic images of water leaving radiance for the coastal test sites of INSEA. We show that the observation operator approach has the potential to allow the consistent mapping of model variables into observed quantities which simplifies the transport of measurement errors and reduces the need for approximations inherent in previous approaches. In conclusion we discuss the future development and potential of inversion of the system in order to obtain more accurate ocean color biogeochemical products (including chlorophyll) from satellite radiance data for eutrophication assessment. We also highlight the additional advantages there may be for ecological models from having stronger links to bio-optics.

\footnotetext{
* Corresponding author at: Institute of Oceanography, Hellenic Centre for Marine Research (HCMR), P.O. Box 2214, 71003 Heraklion, Crete, Greece. Tel.: + 302810 337754; fax: + 302810337822.

E-mail addresses: andyb@her.hcmr.gr (A.C. Banks), pascal.prunet@noveltis.fr (P. Prunet), julien.chimot@noveltis.fr (J. Chimot), ppina.maretec@ist.utl.pt (P. Pina), jerome.donnadille@noveltis.fr (J. Donnadille), eric.jeansou@noveltis.fr (E. Jeansou), muriel.lux@noveltis.fr (M. Lux), pet@her.hcmr.gr (G. Petihakis),gkorres@ath.hcmr.gr (G. Korres), gt@ath.hcmr.gr (G. Triantafyllou), clement.fontana@univmed.fr (C. Fontana), claude.estournel@aero.obs-mip.fr (C. Estournel), caroline.ulses@aero.obs-mip.fr (C. Ulses), lfernandes.maretec@ist.utl.pt (L. Fernandez).
}

\section{Introduction}

Eutrophication is the process by which primary production is enhanced through the increase in the rate of supply of organic matter and thus nutrients to an ecosystem (EEA, 2001; Nixon, 1995). Of particular concern are the effects of excess nutrients introduced by human activities, such as nitrogen in the form of nitrate, nitrite and ammonium and phosphorous in the form of ortho-phosphate. For coastal ecosystems, monitoring and predicting the extent and degree 
of eutrophication can be considered important for environmental and societal reasons. This is because of the potential harmful effects that increasing eutrophication can have on the sustainability of coastal ecosystems and on human health. In severe cases eutrophication can lead to large algal blooms and algal scum, (some of which can be toxic), enhanced benthic algal growth, cycles of bacterial and fungal growth, oxygen depletion, and subsequent changes in the structure and functioning of the marine ecosystem with either radical change or loss of marine flora and fauna (Cloern, 2001 and EEA, 2000; WHO, 2002).

There are a number of major problems in effectively and quantitatively monitoring eutrophication in coastal ecosystems. Firstly, in order to be able to quantify the rate of eutrophication in a particular ecosystem, accurate baseline data is needed. For many coastal regions there is little or no data gathered and where there have been concerted field campaigns gathering a great deal of in situ data, this data is often limited in terms of its spatial coverage or temporal resolution and thus has low statistical power to resolve the questions asked about eutrophication for that area. Secondly, not only can coastal marine ecosystems be very complex in biogeochemical terms but the influence the hydrodynamics of the area have on these ecosystems, particularly in relation to the fate of nutrients entering the system, can further increase the complexity of effective monitoring. Thirdly, it may be important to not only quantify the degree of eutrophication but also to be able to ascertain whether unacceptable or harmful eutrophication has occurred (ERM, 2000). Given the lack of baseline data and the complexity of the systems involved it is very difficult to achieve any accuracy in this using simple biometric or indices based approaches.

The combination of state of the art numerical modeling and remote sensing techniques has the potential to create sophisticated tools that move us closer towards accurately quantifying and monitoring eutrophication. Both biogeochemical and hydrodynamic models aim to describe processes quantitatively and are capable of showing the interaction between state variables in complex systems. Satellite remote sensing of the optical properties of coastal waters can add to this derived biophysical products that are relevant in terms of spatial coverage and spatial and temporal resolution. These products and any ongoing in situ measurements are then best used in assimilation into the coupled models to provide a tool that is capable of revealing the present state of the ecosystem in three dimensions, as well as forecasting the future state in relation to the levels of nutrient inputs. This combination of modeling and remote sensing also has the advantage of being able to quantify possible errors and through assimilation maintain the results closer to the real situation than model free runs (Carmillet et al., 2001; Triantafyllou et al., 2007).

However, products derived from satellite ocean color data continue to suffer from high levels of inaccuracy when compared with in situ measurements of the surface layer of the ocean. The early success of using empirical relationships between chlorophyll and simple band ratios to derive estimates of surface layer chlorophyll from the first ocean color satellite sensor's data, i.e. CZCS (Gordon et al., 1983; Mitchell, 1994), has led mainstream ocean color remote sensing and standard ocean color products towards following this approach for subsequent sensors (e.g. SeaWiFS and MODIS). Chlorophyll has continued to be the main focus product but is only related to one of the optical properties of sea water, namely the absorption of light by phytoplankton, whereas empirical band ratio approaches use wavelength banded water leaving radiance resultant from all absorption and scattering of light by all the optically active components of the ocean surface layer. The assumptions for these algorithms to work are that the inherent optical properties of the sea water are only dependent on clear water and phytoplankton and that there is therefore a very good correlation between blue/green band ratios and the concentration of chlorophyll. For many case-I open ocean situations these assumptions have been shown to have theoretical basis and the potential for remote sensing application (Bricaud et al., 1995; Bricaud et al., 1998; Morel, 1988;
Morel and Prieur, 1977). Furthermore, global empirical algorithms derived from regression analyses of large in situ data bases collected from waters around the world (Morel and Antoine, 2007; O'Reilly et al., 1998,2000 ) have been shown to have practical application within certain accuracy limitations (Bailey and Werdell, 2006; Bailey et al., 2000; Gordon et al., 1983; Gregg and Casey, 2004; Hooker and McClain, 2000; McClain et al., 2000; O'Reilly et al., 1998). Satellite data product accuracy goals generally accepted by the international missions are $\pm 5 \%$ for water-leaving radiances and $\pm 35 \%$ for chlorophyll a in the open ocean (McClain, 2009).

However, the empirical algorithms have a tendency to only perform well for the regions where the in situ data was collected that was used for their creation. The accuracy limit for chlorophyll has been shown to be unrealistic for many regions of case-I open ocean. For example, in Eastern Mediterranean oligotrophic conditions where the concentrations of chlorophyll can be very low (Bricaud et al., 2002; Sancak et al., 2005) or where pigment specific absorption and scattering may be different such as in the Southern Ocean around Antarctica (Arrigo and van Dijken, 2004; Garcia et al., 2005; Garcia et al., 2006; Marrari et al., 2006; Mitchell and Holm-Hansen, 1991; Moore et al., 1999). Some authors have tried to solve these problems by deriving regional empirical band ratio algorithms (e.g. Bricaud et al., 2002; Darecki et al., 2005; Sancak et al., 2005; Volpe et al., 2007), although the range of concentrations where they work can still be a limiting factor and where there is a wide variation in conditions within that region (e.g. the Mediterranean has a strong trophic gradient from West to East) accuracy problems will again be apparent.

Furthermore, it has also been noted in many of the studies cited above and in others particularly dealing with case-II/coastal waters (Sathyendranath and Prieur, 1981; Sathyendranath et al., 1989; IOCCG, 2000 and references contained therein; Defoin-Platel and Chami, 2007) that other optically active components present in the water column, such as non algal suspended particulate matter and colored dissolved organic matter, cause empirical relationships to break down. As stated earlier chlorophyll concentration is only related to one of the inherent optical properties of sea water, absorption of light by phytoplankton, then this should not be of surprise and subsequently leads to chlorophyll concentration accuracy problems from standard ocean color products being particularly pronounced for coastal waters and waters optically classified as Case-II (IOCCG, 2000 and references contained therein). Ironically, this is where the majority of harmful eutrophication takes place and therefore arguably where the accuracy of derived biophysical products, including chlorophyll, from ocean color remote sensing is required to be highest.

We suggest that using approaches that do not fully exploit remote sensing optical data through a parameterization of the optical properties of sea water, is the main reason for the poor performance of many ocean color products when compared with in situ data. Recently more research is focusing on developing bio-optical algorithms based on inherent optical properties (IOCCG, 2006 and references contained therein; Werdell, 2009) that have the potential to increase the accuracy of ocean color products for case-II/coastal waters (and also case-I waters). Furthermore, satellite sensors are now reaching the accuracy and resolution compatible with coastal scales and their space/time coverage opens unique opportunities for monitoring the marine environment. During the INSEA project the potential positive role that remote sensing products can play in coastal eutrophication assessment systems using assimilation into coupled hydrodynamic-biogeochemical models has been shown (see Korres et al., 2012-this issue). The main preliminary conclusions demonstrated that satellite data can have a positive contribution in improving the modeling of ecological variables such as chlorophyll. However, as outlined above, the information contained in the data is not optimally exploited.

The recent research efforts on developing bio-optical algorithms based on inherent optical properties introduces a more general requirement of 
coastal ocean color remote sensing, i.e. to properly consider and control the complex relationship between chlorophyll and other bio geochemical variables on the one hand and the remotely sensed radiances on the other hand. Such complexity, and in particular the specificities of coastal waters, is very difficult to properly represent in empirical data processing schemes retrieving ecological variables from measured radiances, because of the necessary parameterization of such processing. As another example of the limitation of empirical algorithms, hypotheses on the vertical structure of optically active variables are fixed, avoiding any fit of this structure to the real situation, and leading to inconsistencies in the retrieved product. On the other hand, operational biogeochemical models, used to exploit these products, properly reproduce most of the significant features of coastal waters, as they are defined and tuned for this purpose.

Considering all of the above, an alternative approach is proposed in this work in order that remote sensing can be used routinely by coastal water management systems. This is to develop an operator, in addition to the model, which consistently maps the model variables into observed quantities, properly taking into account the complex relationships between the different quantities. This operator is the so-called 'observation operator'. This approach has been developed for assimilation in atmospheric physics and remote sensing of meteorology (Ide et al., 1997; Lorenc, 1986; Pailleux, 1990) but could be equally applicable to ocean optics.

In the proposed approach, the biological parameters are transformed into synthetic water-leaving radiance, which can be compared with observed water leaving radiances. We suggest that this way of exploiting the observations optimizes the use of ocean color information, because all the hypotheses on the nature, proportion and vertical distribution of optically active variables are controlled by the model (and can be potentially adjusted). This includes what has been termed the forward problem of ocean optics (IOCCG, 2006) which is to predict the spectral distribution of the waterleaving radiance based on a quantitative description of the Inherent Optical Properties (IOPs) of all the components in the ocean, using the equation of radiative transfer. It is a model-to-satellite approach divided into two parts: the relationship between biogeochemical parameters and the IOPs; and the relationship between the IOPs and the radiance distribution (Fig. 1 ).

The availability of such an observation operator allows a direct and quantitative use of the measured radiances together with the numerical modeling of physical and bio-geochemical ocean processes. As stated from works in atmospheric physics and meteorology (e.g., Eyre, 1989; Pailleux, 1990; Prunet et al., 2000) this appears as the more efficient way of exploiting the information contained in the remotely sensed data. The link between state variables considered in the model and the observed remote-sensed data is complex. Thus, the retrieval of model variables from remotely sensed measurements is an ill-posed problem, which requires additional independent information in the retrieval process, as well as the observation. If this independent information is not consistent with, and not controlled by the model, which will use the retrieved quantities, two problems will occur: biases in the retrieval quantities, and misinterpretation of the noise figures associated with the retrieved quantities (Eyre, 1989; Rodgers, 2000).

The development of an observation operator, able to transport model state variables into observed quantities, provides a consistent set of approaches and methodologies for i) quantitative comparisons of models and remotely sensed observations, ii) proper inversion of modeling variables from remotely sensed data (Eyre, 1989) and iii)

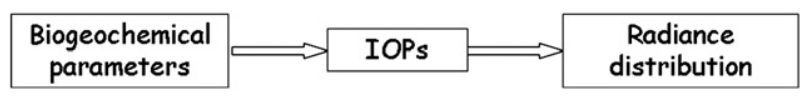

Fig. 1. Model to satellite 'forward' approach. direct assimilation of radiances in the model (Eyre et al., 1993; Pailleux, 1990; Prunet et al., 2000).

This study is a preliminary attempt at implementing this approach for coastal eutrophication problems as addressed in the INSEA project. It focuses on methodological aspects, by describing the approach and its application on illustrative examples, and by giving theoretical discussion of its interest and potential. An observation operator is developed and tested on the sites and with the modeling tools studied by INSEA (Section 2). First tests of comparison with SeaWifs and MODIS remote sensed observations are presented and discussed (Section 3). Concluding, Section 4 discusses the potential relevance of the observation operator methodology and describes the proposed framework and the next steps to be addressed by our work for the demonstration of interest and the exploitation of this approach : 1) quantitative validation of the observation operator approach through direct comparison of simulated and observed radiances at the INSEA sites; 2 ) demonstration of the potential of this approach through inversion experiments controlled by the models, for retrieving remotely-sensed chlorophyll products consistent with in situ measurements at the INSEA sites; and 3) development of operational scenarios for the use of the observation operator to properly integrate remote sensing data in the model-based management tools for coastal zone eutrophication proposed by INSEA.

\section{Materials and method}

\subsection{Observation operator approach}

\subsubsection{Principles and possible outcomes of the approach}

When addressing the question of exploiting satellite observations in concordance with a modeling system, basic problems are encountered. The observations are not generally applied at model grid points, but at observation locations; satellites measure radiances or reflectivities, and not directly (or uniquely) chlorophyll or phytoplankton concentration. Thus, a model equivalent of the observations needs to be calculated to enable comparison in the observation space. This is done with the observation operator.

\subsubsection{Definitions. The observation operator provides the quantita-} tive and well-defined link between the model variables and the observation. It may be a simple interpolation from model grid to observation location for direct observations, or it may possibly perform additional complex transformations of model variables.

- The tangent linear of the observation operator can be computed. It consists of the partial derivatives of the observation operator with respect to all its inputs, expressing the variation of the observation operator in the vicinity of the modeling state. This is sometimes referred to as the Jacobian of the observation operator.

2.1.1.2. Properties. - Observation operator accuracy: The proper consideration of observation errors is possible and crucial when using observation operators. If the accuracy of the observation operator is poor, then the corresponding observations will be of little value for comparison with the modeling system. The observation error is the sum of measurement error and the representativeness error, which is the error associated with assumptions/ approximations of the observational operator, or of the retrieval/inversion process. It can be a large component of the observation error, and the observation operator allows the characterization of this error term in the observation space. 
- Multivariate operator: One observation can depend on several model quantities. This is the multi-variate observation operator.

- Non linear operator: In case of complex observation operators, depending for example on ocean and atmospheric states, it can be non linear.

- Observation information content: For complex and non linear operators the study of the Jacobian can reveal which model components have been observed or not, and highlight observation sensitivities to model variables. It thus allows us to quantitatively draw the effective information carried out by the observation on the modeling system, and to avoid misinterpretation.

- Ambiguity: The fact that some observation operators may be multivariate leads to ambiguity. In this case there is one observation, but many model components to constrain with. This is the classical retrieval problem in its general form. The use of the observation operator, initialized by modeling system information, in an optimal estimation retrieval/assimilation scheme is the way to resolve such ambiguities statistically, by allowing a proper merging of modeling information with corresponding error characteristics and the information from neighboring observations as constraints.

2.1.1.3. Expected advantages. From the above considerations, the message we would like to give with the present work is that, considering the specificities of the problem of observing the biogeochemical state of coastal waters from space-based remote sensing ocean color measurements, an observation approach is a more appropriate way to proceed. Indeed, this is a typical problem of indirect observation of a multivariate state with multiple and complex relationships between state variables of interest and observed quantities. The classical approaches currently used operationally to derive state variables from these measurements fail in general to properly deal with most of the specificities listed above, i.e.:

- incorrect consideration of observation error by neglecting error representativeness;

- incomplete and/or improper consideration of multivariate characteristics of the observations;

- linear approximation for non linear problems;

- lack of consistent analysis of the information content of the observation with respect to modeling system needs;

- solutions for resolving ambiguities not consistent with the use of the modeling systems.

On the other hand, the proposed approach is able to properly account for all these points, and benefits from an extensive background and experience acquired in meteorology and physical oceanography. Typically, the expected qualitative gaps of such an approach cover three main aspects:

1. Consistency of ocean color products with modeling, forecast and management systems using them: the observation operator will use the modeling system information to solve for ambiguities and ill-posed aspects of the use of ocean color data information;

2. Reduction/removal of problems of bias and misinterpretation of case II ocean color products: proper consideration of error characterization, and the use of the Jacobian for analysis of information content of the data will help to reduce the incorrect use of the information;

3. Extraction of new information from ocean color data: the combination of the above two points, by allowing precise identification of what is the useful information present in the observation to improve modeling systems will allow the optimal exploitation of the data. Preliminary analyses presented in this work suggest the capability of ocean color data to capture information on the vertical structure of water constituents, and the possibility for distinction between different optically active constituents.
2.1.2. Description and implementation of the observation operator system

As outlined above, an observation operator was implemented in this study. Essentially, for this implementation it was created from an ensemble of operators transferring the biogeochemical state vector (containing the pertinent variables of the ecological model) into the equivalent of observed quantities, at observation location, through the computation of their optical behavior in the water column. The observed quantity considered in this work is the remote sensing ocean color synthetic measurement at the water surface.

Fig. 2 schematically represents the main steps of the observation operator system in providing simulated water leaving radiance measurements and synthetic ocean color images. As inputs, the observation operator requires data from the ecological model and from observations:

- the model provides the ecological variables profiles for the location considered on the vertical grid of the model;

- the observation data provides the observation location, the measured wavelengths and the instrument response function to be considered for the simulation.

The first processing step was the horizontal interpolation of the simulated profiles onto the observation location grid (as a first step the method used was the closest biological model grid point). It also included a vertical interpolation onto the vertical grid adapted to the computation of the radiative transfer in the water column.

The observation operator can be interfaced with different biogeochemical models. In the present study, the European Regional Seas Ecosystem Model (ERSEM, Baretta et al., 1995; ERSEM-I, 1995, 1997) and the ECO3M-MED based model (Baklouti et al., 2006a, 2006b) were considered, and provided specific biogeochemical state vectors as input to the observation operator system. Subsequently, in a second step a number of the biogeochemical model variables at the observation location were merged into a few variables that characterize chlorophyll, Colored Dissolved Organic Matter (CDOM) and inorganic suspended matter profile concentrations (see previous section). These are the variables that are required as input for the radiative transfer module.

The radiative transfer module was divided into two parts: the first part is a bio optical model that derives IOPs from chlorophyll, CDOM and inorganic suspended matter concentrations; this is the third step of the processing. The second part computed the spectral intensity of the light (spectral radiance) reaching the sea surface by describing quantitatively all the absorption, scattering and reflection characteristics of the optical components of the ocean; this is the fourth step of the processing. The simulation was based on the use of the optical marine water radiative transfer model HYDROLIGHT 4.3 (Mobley, 1994). The code has been converted from Windows to Linux operating system for the purpose of our simulations, which allowed the easy coding of input and output modules around the central HYDROLIGHT model. For the initialization of the radiative transfer equation it was necessary to fix the following parameters: windblown surface; nature of the bottom of the water column; sun and sky radiance incident on the sea surface; and the absorbing and scattering properties of the water body (Mobley and Sundman, 2006).

Finally in the fifth step, the computed spectral radiance was convolved with the instrument response functions, in order to provide the synthetic radiance as seen by satellite sensors.

\subsection{Test sites}

Two INSEA project sites were used to provide input for and test the observation operator system. The first was the Gulf of Lion, Northwestern Mediterranean (see Fig. 3 below), which contains a shallow semi-enclosed bay covering $42 \mathrm{~km}^{2}$ with a mean depth of $8 \mathrm{~m}$ called the Gulf of Fos . This coastal area is an atidal, wind driven system, and 


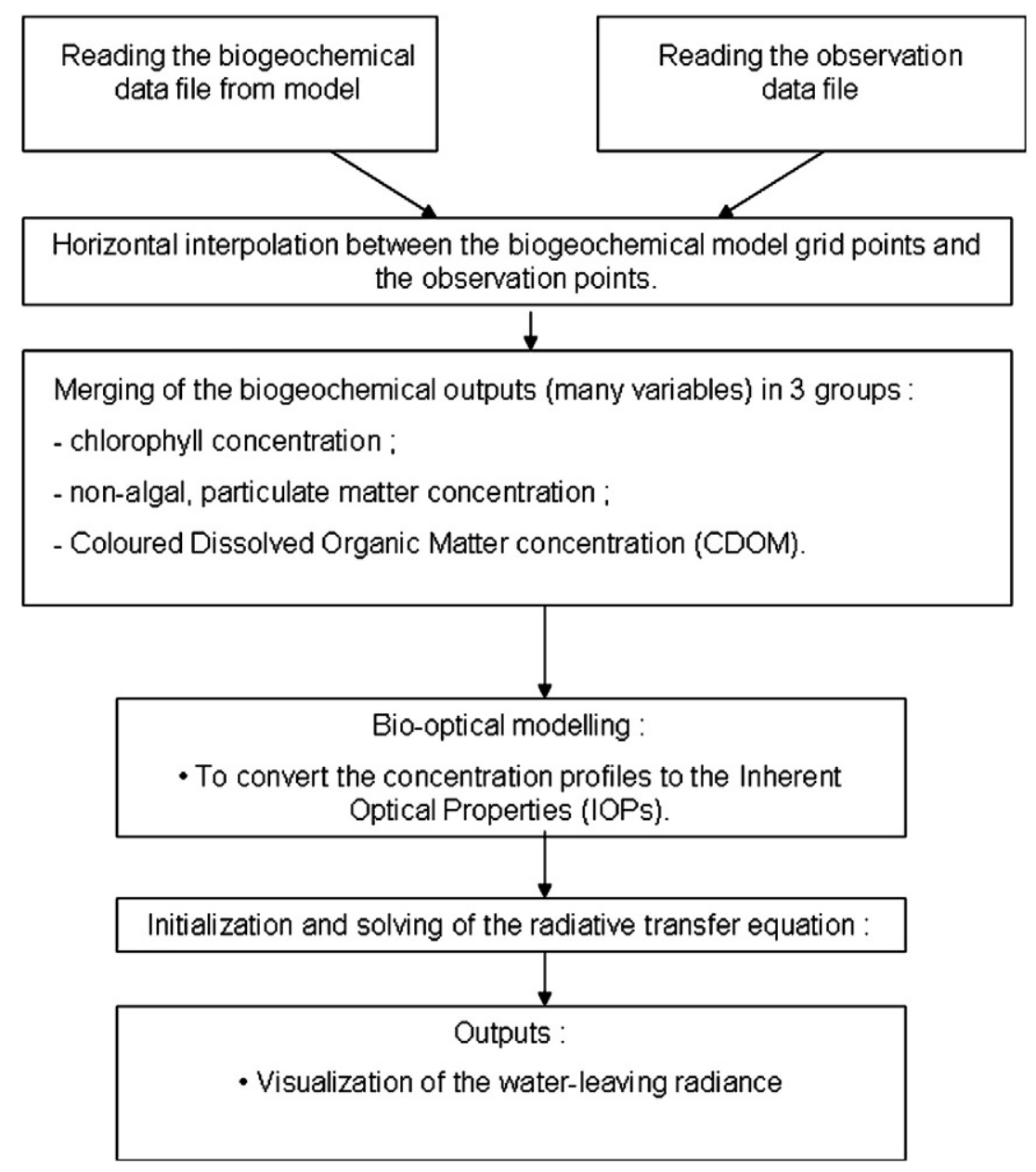

Fig. 2. Design of the observation operator system in the forward mode.

is under the intermittent influence of the discharge of the Rhone River. The northern and eastern coastal part of the Gulf of Fos is also bordered by chemical, fuel and steel-work plants. Any resultant eutrophication can have important economic consequences for the region especially because of the culture of mussels in the Anse of Carteau in the western part of Gulf of Fos which requires good water quality. The Gulf of Lion's fisheries sector also depends on the water quality of the littoral zone which is a nursery for a number of species. The region of the Rhone delta is also characterized by a high diversity of fauna which depends directly on the quality of the environment controlled by the degree of eutrophication of the area.

The second test site was Pagasitikos, a semi-enclosed gulf located in the western Aegean part of the Eastern Mediterranean (see Fig. 4 below). The mean depth is $69 \mathrm{~m}$ characterizing the system as shallow

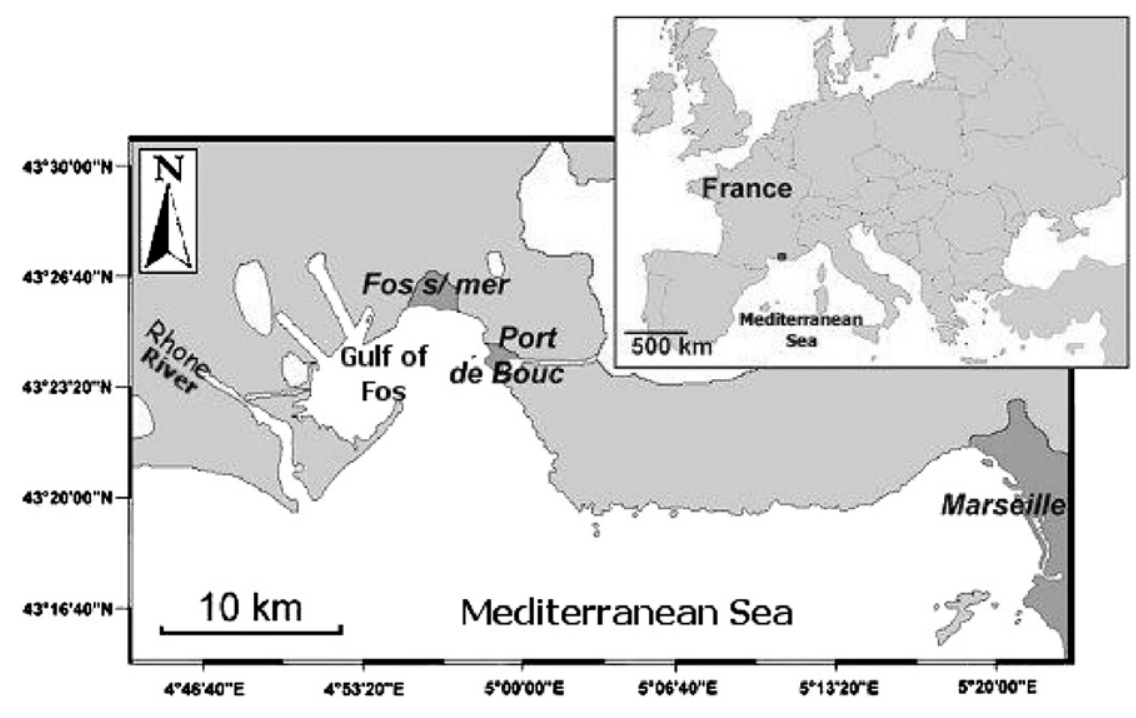

Fig. 3. The Gulf of Lion containing the Gulf of Fos. 
while the deepest area $(108 \mathrm{~m})$ is found at the eastern part of the gulf where larger gradients are observed. The total area is $520 \mathrm{~km}^{2}$ with a total volume of $36 \mathrm{~km}^{3}$ connected with the Aegean Sea and north Evoikos through the narrow $(5.5 \mathrm{~km})$ and relatively deep $(80 \mathrm{~m})$ Trikeri channel. Although the ribbon development in the coastal areas is not considered significant, at the northern part of the gulf there is the city of Volos with a population of 120,000 and major industrial production. Development started during the 1960 s characterized by population explosion, industrialization and intensive agriculture, affecting the littoral and sub-littoral systems, which received significant quantities of rural, industrial and agricultural effluents. Nitrogen, phosphate and sulfur are used annually in the scattered farmlands along the coastline where intensive agriculture of cereals and cotton is practiced. Although in the wider area there are no major rivers, it is believed that a significant proportion of these nutrients enter the system during winter through a network of small seasonal streams.

\subsection{Biogeochemical model configurations and outputs}

For the Gulf of Lion an indication of the relevant biogeochemical model outputs can be seen in Table 1, along with the coupled hydrodynamic model and meteorological model used to gain atmospheric forcing data for the system. The ecological model used is based on the ECO3M-MED model (Baklouti et al., 2006a, 2006b) and is still under collaborative development at the Laboratoire d'Océanographie Physique et Biogéochimique (LOB) of the Centre National de la Recherche Scientifique (CNRS) and the Laboratoire d'Aérologie (LA) of the Observatoire Midi Pyrénées.

As seen in Table 1, we used the primitive equation ocean circulation model SYMPHONIE (Marsaleix et al., 2008; Ulses et al., 2008). This model was successfully used at different time and space scales to study the key physical processes of the area (Estournel et al., 2001, 2003; Herrmann et al., 2008; Ulses et al., 2008).

We used a regional scale configuration (40 sigma-step vertical levels and $3 \mathrm{~km}$ horizontal resolution) of the model, implemented in the

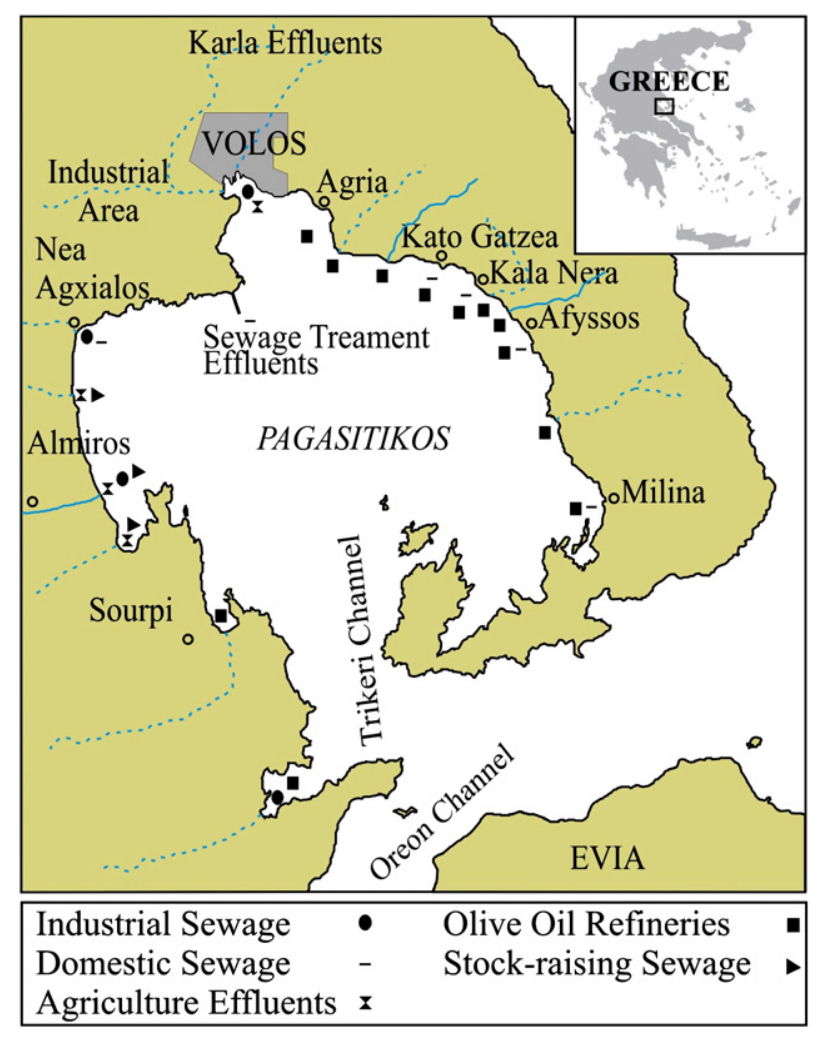

Fig. 4. Pagasitikos Gulf.
Table 1

Models used for the Gulf of Lion simulations.

\begin{tabular}{|c|c|c|c|}
\hline Local models & Model & Inputs & Outputs \\
\hline $\begin{array}{r}\text { Hydrodynamics } \\
\text { and transport }\end{array}$ & SYMPHONIE & $\begin{array}{l}\text { Meteorological } \\
\text { forcing, river } \\
\text { run-off, tides }\end{array}$ & $\begin{array}{l}\text { Ocean currents, temperature, } \\
\text { salinity, mixed layer depth. }\end{array}$ \\
\hline Ecological & CNRS-LOB & $\begin{array}{l}\text { Light, } \\
\text { temperature, } \\
\text { transport, } \\
\text { properties loads }\end{array}$ & $\begin{array}{l}\text { Data related to eutrophication } \\
\text { i.e. concentrations of } \\
\text { particulate and dissolve } \\
\text { carbon chlorophyll, nitrate, } \\
\text { phosphate, silicate, ammonia, } \\
\text { diatoms, flagellates, detritus, } \\
\text { oxygen, primary production, } \\
\text { suspended matter }\end{array}$ \\
\hline Meteorological & ALADIN & $\begin{array}{l}\text { Atmospheric } \\
\text { forcing data }\end{array}$ & $\begin{array}{l}\text { Heat fluxes, surface } \\
\text { temperature, humidity, wind } \\
\text { shear velocities }\end{array}$ \\
\hline
\end{tabular}

framework of the Mediterranean Forecasting System Toward Environmental Predictions (MFSTEP) program (Estournel et al., 2007). The model extends from the Balearic Islands to the Ligurian Sea as indicated in Fig. 5. It is run using initial and boundary conditions from the basin scale Ocean Parallelise (OPA) model (Madec et al., 1997). For the atmospheric forcing, the 6-hour outputs (radiative solar and long-wave fluxes, surface pressure, air temperature, relative humidity and wind velocity) of the high-resolution meteorological model ALADIN from Météo-France (http://www.cnrm.meteo.fr/aladin/) were used. The wind stress and the heat fluxes were computed with bulk formulae (Geernaert, 1990) using the air parameters provided by the ALADIN model and the sea surface temperature computed by the SYMPHONIE model. Discharges of the Rhône, Aude, Hérault, Orb and Ebro rivers were prescribed using in-situ daily data (BANQUE HYDRO, http:// www.hydro.eaufrance.fr/; SAIH Ebro, http://195.55.247.237/saihebro/ index.php).

The biogeochemical model includes 33 state variables. It is a multi-nutrient and multi-plankton functional types (Le Quéré et al., 2005) model since this code simulates the dynamics of several biogeochemical decoupled cycles of biogenic elements (carbon, nitrogen, phosphorus and silica) and pelagic plankton groups. It is defined by three size groups of phytoplankton (pico-, nano- and micro-phytoplankton), three size groups of zooplankton (nano-, micro- and meso-zooplankton), heterotrophic bacteria, two size classes of particulate organic matter, dissolved organic matter and four inorganic nutrients (nitrate, ammonium, phosphate, silicate). The internal carbon/nitrogen and carbon/ phosphorus ratios are constant for heterotrophic groups and variable for autotrophs. The representation of the phytoplankton processes is derived from the model ECO3M (Baklouti et al., 2006b). In the present work this basis model has increased in complexity and the different phytoplankton functional types are computed in terms of carbon, nitrogen, phosphorus, silica (only for the third phytoplankton group) and chlorophyll contents with potential multi-nutrient limitation for their growth. The heterotroph model is an adapted version of the stoichiometric model developed by Anderson and Pondaven (2003) and applied at the study area by Raick et al. (2005).

This model was first implemented in a $1 \mathrm{D}$ version in the FEMME environment (Flexible Environment for Mathematically Modeling the Environment; Soetaert et al., 2003) for calibration tests on the numerous parameters. We applied it for year 2004 at the high frequency monitored Dynamique des Flux de mAtière en MEDiterranée (DYFAMED) station (http://www.obs-vlfr.fr/dyfBase), where advection is considered to be generally low.

For the initialization we applied horizontally homogeneous fields. We initialized nutrients in deep areas (depth $>1000 \mathrm{~m}$ ) using a winter average observed profiles at DYFAMED. Moreover, to take into account the poverty of nutrients in the general circulation flowing along the continental slope, in shallower areas (depth $<1000 \mathrm{~m}$ ) these were 


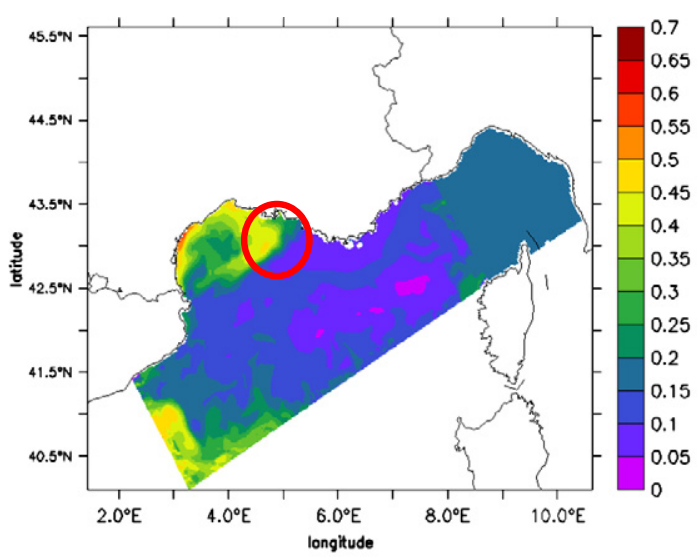

Chlorophyll concentration $(\mathbf{m g} / \mathbf{m} 3)$

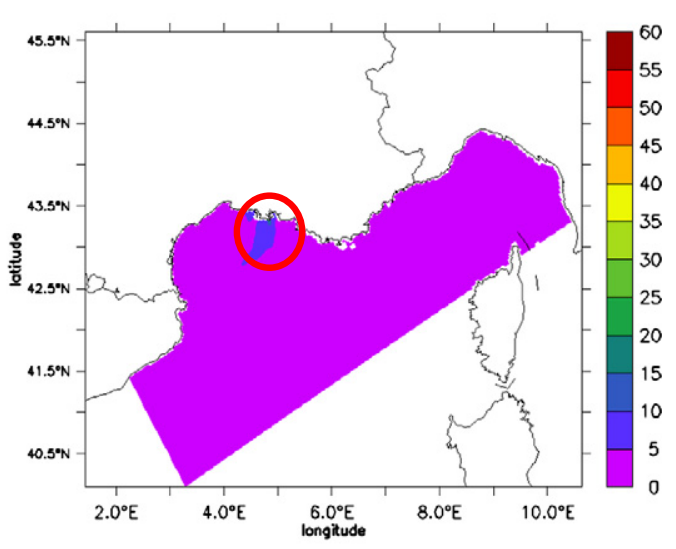

Particulate organic carbonate concentration $(\mathrm{mmolC} / \mathrm{m3})$

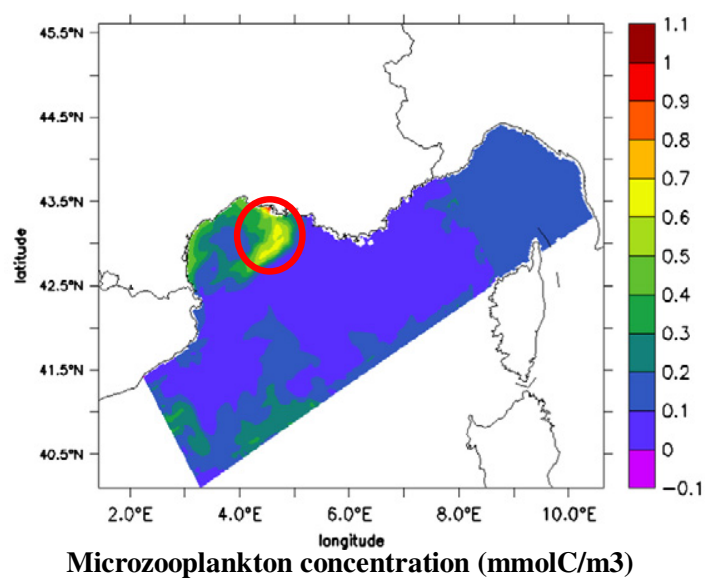

(

: Structure of high values of ecological concentrations

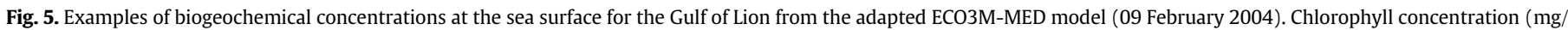
$\mathrm{m}^{3}$ ), Particulate organic carbonate concentration $\left(\mathrm{mmol} / \mathrm{C} / \mathrm{m}^{3}\right)$, microzooplankton concentration $\left(\mathrm{mmol} / \mathrm{C} / \mathrm{m}^{3}\right)$ : Structure of high values of ecological concentrations.

initialized using a mean observed profile in the northern current during the winter MOdelisation et Observation du golfe du Lion (MOOGLI) cruise (Durrieu de Madron et al., 2003). The initialization of the other state variables (bacteria, zooplankton, Dissolved Organic Matter or DOM, Particulate Organic Matter or POM) was done according to literature and available data from different years. Perpetual preliminary simulations of year 2004 were performed to obtain coherent biogeochemical variables. Steady state was reached after two years of simulation.

Nitrate, ammonium, phosphate and Dissolved Organic Carbon (DOC) concentrations were prescribed at the Gulf of Lion river mouths using in situ monthly data (source : http://www.rdbrmc.com/cartordbrmc/). Concentrations of Dissolved Organic Phosphorus (DOP), Dissolved Organic Nitrogen (DON) and POM were estimated from these data and relations deduced from literature (Moutin et al., 1998; Sempéré et al., 2000) and recent high-frequency data (pers. comm. Raimbault). At each grid point of the open boundaries, the biogeochemical state variables were computed by a 1D version of the ecosystem model. Fluxes of nutrients at the surface were not taken into account.

Because an on-line coupling would have been computationally too expensive, simulations with the hydrodynamic model were first performed, storing daily averaged current, turbulent diffusion coefficient and temperature. Then the biogeochemical model was run using the circulation results as forcing functions, with a 2-hour time step.
Similarly, an indication of the relevant biogeochemical model outputs for Pagasitikos Gulf can be seen in the table below along with the coupled hydrodynamic model and meteorological model used to gain atmospheric forcing data for the system. The ecological model used is a Hellenic Centre for Marine Research-Plymouth Marine Laboratory adaptation of the European Regional Seas Ecosystem Model (Baretta et al., 1995; ERSEM-I, 1995, 1997).

As shown in Table 2, the 3D ecosystem modeling for Pagasitikos Gulf consisted of the on-line coupling of two sub-models: the three-dimensional Princeton Ocean Model (POM) (Blumberg and Mellor, 1987) and the ecological model based on the European Regional Seas Ecosystem Model (ERSEM) (Baretta et al., 1995). The physical model describes the hydrodynamics of the area and provides the background physical information to the ecological model. These were parameterized and tuned for the Pagasitikos Gulf ecosystem.

The computational domain for Pagasitikos Gulf modeling was between $22.8125^{\circ} \mathrm{E}$ to $23.3025^{\circ} \mathrm{E}$ and $39.0^{\circ} \mathrm{N}$ to $39.43^{\circ} \mathrm{N}$. A Cartesian coordinate system consisting of $49 \times 45$ grid points with a horizontal grid resolution of $0.01^{\circ}$ both in latitude and longitude was used. There were 25 vertical layers of variable thickness with a logarithmic distribution near the surface and the bottom giving greater resolution and accounting better for where velocity gradients are larger.

This high resolution coastal model for Pagasitikos Gulf was nested into the lower resolution $\left(1 / 30^{\circ}\right)$ model of the Aegean Sea which itself 
Table 2

Models used for the Pagasitikos Gulf simulations.

\begin{tabular}{|c|c|c|c|}
\hline Local models & Model & Inputs & Outputs \\
\hline Hydrodynamics and transport & POM & $\begin{array}{l}\text { Meteorological forcing, } \\
\text { river run-off, tides }\end{array}$ & Ocean currents, temperature, salinity, mixed layer depth. \\
\hline Ecological & ERSEM adapted & $\begin{array}{l}\text { Light, temperature, } \\
\text { transport, properties loads }\end{array}$ & $\begin{array}{l}\text { Data related to eutrophication, i.e. concentrations of particulate and } \\
\text { dissolved carbon chlorophyll, nitrate, phosphate, silicate, ammonia, } \\
\text { diatoms, flagellates, detritus, oxygen, primary production, suspended matter }\end{array}$ \\
\hline Meteorological & Eta/SKIRON and RAMS & Atmospheric forcing data. & Heat fluxes, surface temperature, humidity, wind shear velocities \\
\hline
\end{tabular}

was nested into a $1 / 10^{\circ}$ model for the entire Mediterranean Sea (part of the Greek POSEIDON system, www.poseidon.hcmr.gr). All three models were forced with the $72 \mathrm{~h}$ forecasting fields of the POSEIDON meteorological model, which is an implementation of the ETA limited area model in the Mediterranean and the Aegean Seas with a resolution of 20 and $10 \mathrm{~km}$ respectively. The air-sea interaction scheme is the same as the one described in detail in Korres et al. (2002) for the Aegean Sea model.

More specifically for the ecological model a coherent system behavior is achieved by considering the system as a series of interacting physical, chemical and biological complex processes (Baretta et al., 1995). The ecosystem is described using an adapted 'functional' group approach while trophic level, size similarity classes and feeding methods separate and subdivide organisms.

Fluxes of carbon and nutrients are used in the model to describe the dynamics between functional groups including physiological (ingestion, respiration, excretion, egestion, etc.) and population processes (growth, migration and mortality). Horizontal advection and dispersion and vertical sedimentation and dispersion are the main physical processes affecting the biological constituents. The horizontal processes can operate on scales of tens of kilometers and the vertical processes on tens of meters (Baretta et al., 1995). Furthermore, there are the biologically driven carbon dynamics which are coupled to the chemical dynamics of nitrogen, phosphate, silicate and oxygen.

A food matrix was constructed for the trophic relations between functional groups with the food web modulated for Pagasitikos Gulf (see Petihakis et al., this issue). As food matrix values tend to be specific and different for each ecosystem, with each element of the matrix representing the percentage of availability/preference of that particular trophic level with regard to the others, the matrix imposes a particular model implementation for Pagasitikos Gulf. The initialization and model run parameter set for Pagasitikos come from the 1D model (Petihakis et al., 2000).

Moving to the 3D coupled model implementation, as was the case for this study, for each functional group of the pelagic system the following equation is solved for the concentration of $\mathrm{C}$ :

$$
\begin{aligned}
\frac{\vartheta C}{\vartheta t}= & -U \frac{\partial C}{\partial x}-V \frac{\partial C}{\partial y}-W \frac{\partial C}{\partial z}+\frac{\partial}{\partial x}\left(A_{H} \frac{\partial C}{\partial x}\right) \\
& +\frac{\partial}{\partial y}\left(A_{H} \frac{\partial C}{\partial y}\right)+\frac{\partial}{\partial z}\left(K_{H} \frac{\partial C}{\partial z}\right)+\sum B F
\end{aligned}
$$

where $U, V, W$ represent the velocity field, $A_{H}$ is the horizontal viscosity coefficient, and $K_{H}$ is the vertical eddy mixing coefficient (provided by POM). $\sum B F$ is the total biochemical flux, calculated by the model as a summation for each pelagic group.

Eq. 1 is approximated by a finite-difference scheme analogous to the equations of temperature and salinity (Petihakis et al., 2002) and is solved in two time steps (Mellor, 1991): an explicit conservative scheme (Lin et al., 1996) for the advection, and an implicit one for the vertical diffusion (Richtmyer and Morton, 1994). Finally, coupling between the pelagic and benthic systems is implemented in the model as simple benthic returns which include organic detritus settling into the benthos and nutrient fluxes diffusing in and out of the sediment.

The output from the biogeochemical models needed to be transformed into inputs that could be accepted by the next stage of the forward modeling process (i.e. bio-optical modeling and radiative transfer, see below). Required inputs to 4 parameter bio-optical models are chlorophyll concentration profiles, non-algal suspended particulate matter concentration profiles, and CDOM concentration profiles. The IOPs of clear water are dealt with by standard models implemented as part of biooptical and radiative transfer modeling. The pelagic state variables output from the biogeochemical models (e.g. from ERSEM: chlorophyll; diatoms $(20-200 \mu \mathrm{m})$; nanophytoplankton $(2-20 \mu \mathrm{m})$; picophytoplankton $(0.2-2 \mu \mathrm{m})$; large phytoplankton $(20-200 \mu \mathrm{m})$; pelagic bacteria; heterotrophic nanoflagellates $(2-20 \mu \mathrm{m})$; microzooplankton (20$200 \mu \mathrm{m}$ ); mesozooplankton (omnivorous); mesozooplankton (carniverous); dissolved organic matter labile; dissolved organic matter carbohydrates; particulate organic carbon; nitrate; ammonium; phosphate; silicate; reduction equivalents; and oxygen) were therefore combined in the following manner:

i. Chlorophyll was a state variable in both models and these profiles were therefore taken directly from the output of the models.

ii. Suspended particulate matter (non-algal) profile calculation required the summation of all organic (non-algal) and non-organic particles in the water column that can absorb or scatter light. Therefore, as an example from the HCMR ERSEM model state variables the following were summed: pelagic bacteria; heterotropic nanoflagellates; microzooplankton; mesozooplankton; and particulate organic carbon. Added to this was the estimate of sediment/silt that is used as an input or forcing parameter to the model. This parameter is related to the background extinction coefficient used in the model and is generally estimated based on secchi disk, CTD or other light profile field measurements.

iii. CDOM concentrations were not state variables for the models. However, these were estimated as a percentage of the total dissolved organic matter concentration.

\subsection{Satellite data}

Sea viewing Wide Field of view Sensor (SeaWiFS) and MODerate resolution Imaging Spectroradiometer - Aqua (MODIS-Aqua) data were obtained for both test sites from the NASA ocean color web site (http:// oceancolor.gsfc.nasa.gov). These data were level 2 full resolution local area coverage data with a spatial resolution of $1.13 \mathrm{~km} \times 1.13 \mathrm{~km}$ and $1 \mathrm{~km} \times 1 \mathrm{~km}$ respectively. The data for the test sites were extracted and processed to water leaving radiances using the NASA SeaDAS software which is a comprehensive image analysis package for the processing, display, analysis, and quality control of ocean color data (http://oceancolor. gsfc.nasa.gov/seadas). Ancillary data, such as solar zenith, solar azimuth, view zenith, view azimuth, wavelength and bandwidth, were simultaneously extracted.

\subsection{Configuration for the first evaluations of the observation operator system}

The observation operator experiments were designed as follows:

i. As a first approximation, the water-leaving radiance was modeled at single wavelengths for each comparison with observation data (555 nm for SeaWifs and $412 \mathrm{~nm}$ for MODIS). The wavelengths simulated were chosen based on their potential 
utility for the observation of chlorophyll and the other parameters. CDOM absorption contains high values in the blue bands and the blue-green bands are known to be sensitive for chlorophyll detection. Therefore, HYDROLIGHT solved the monochromatic radiative transfer equation with parameters such as IOPs being taken equal to their values at the specified wavelengths;

ii. Information about the wind-blown surface (speed and horizontal direction) can be specified for HYDROLIGHT to better assess the optical reflection and transmission properties of the sea surface. In the present exercise, the wind-blown surface was set to $0 \mathrm{~m} . \mathrm{s}^{-1}$;

iii. As stated in i., the simulations by the observation operator were realized at single wavelengths, even though the effects of inelastic scattering can be parameterized in HYDROLIGHT for a multi-wavelength run. Therefore, phenomena such as chlorophyll and CDOM fluorescence and Raman scattering are considering as negligible in the present exercise.

iv. The bottom boundary is described in the model in terms of a bidirectional reflectance distribution function (BRDF). In our simulations, the bottom boundary was considered as an infinitely deep, i.e., homogeneous water body below a given depth Zmax required as input by the user. Below this depth, the IOPs are put equal to the values at depth $=Z$ max. Therefore, the radiance computed by the radiative transfer model is obtained by the IOPs computed from the model concentrations contained between the surface and the depth Zmax, and constant IOPs, below Zmax are equal to the IOPs at the depth Zmax (Mobley and Sundman, 2006). In this case the bottom boundary was ignored (i.e. considered infinitely deep). This assumption is correct only for the deeper parts of the sites studied, i.e. where the euphotic zone does not extend to the bottom;

v. CDOM absorption was estimated directly inside the HYDROLIGHT model. CDOM absorption $\left(a_{c d o m}\right)$ is modeled as an exponential decaying function of depth $(z)$ and of wavelength $(\lambda)$ from the value at $440 \mathrm{~nm}$ :

$$
a_{\text {cdom }}(z, \lambda)=0.2 a_{\text {chl }}(z, 440) \exp [-0.014(\lambda-440)]
$$

The CDOM absorption varies with the chlorophyll absorption $a_{\mathrm{chl}}$ at $\lambda=440 \mathrm{~nm}$. This formulation from the chlorophyll-specific absorption coefficient $\left(a_{\mathrm{chl}}\right)$ used by HYDROLIGHT is taken from Prieur and Sathyendranath (1981).

vi. For these demonstration simulations, the sky conditions are assumed to be clear, as was the case for the satellite imagery used for comparison. HYDROLIGHT is provided with a model called RADTRAN (Gregg and Carder, 1990) which predicts sky radiances and diffuse and direct sky irradiances at $1 \mathrm{~nm}$ resolution. At this stage, it is assumed that this model is sufficiently good and use default atmospheric parameters. In the future, a more sophisticated model for sky radiance and irradiance is planned as part of the system to account for varying atmospheric conditions;

vii. The radiances compared (between simulations and observations) are from the sea urface. As a consequence, the radiances simulated are only linked to biogeochemical variables. The exemplar observation data are assumed to have good atmospheric correction applied;

viii. The radiative transfer model can provide accurate values for the optical properties (including remote sensing reflectance and downwelling diffuse attenuation) for a range of conditions and for all realistic observation angles. The radiative transfer model output is very dependent on the angular distribution of the downwelling radiance and the transmission through the air-sea interface. In particular, these angles are very useful for sensitivity analysis and/or error assessment studies in remote sensing. Therefore, the angular information available in each observation data set, and which varies across each scene, was included in the simulations:

- for the SeaWifs simulation, the solar zenith angle was taken into account and the water-leaving radiance was modeled for a nadir view;

- for the MODIS simulations, the solar and view angles (zenith and azimuth) were taken into account in the simulation, for each point on the grid.

ix. The observation operator was evaluated using a SeaWiFS dataset for the Gulf of Lion from 09 February 2004 and on a MODIS dataset for Pagasitikos Gulf from 18 August 2003.

\section{Results and discussion}

\subsection{First evaluation: The Gulf of Lion}

This evaluation facilitated the obtaining of the first results of the operator and the initial evaluation of the software application in coastal waters for one of the areas of interest. This test case was simulated at $555 \mathrm{~nm}$ wavelength. High concentrations of biogeochemical variables observed in the grid model at the coast cannot be compared to the values of radiance on this image. Indeed, the near coastal areas are not present in the observation grid. The first results obtained from the solving of the radiative transfer equation are compared with the observation data. The purpose of this initial run was to detect similar and different structures between the synthetic and observed waterleaving radiances.

The main point of interest in Fig. 5 was the detection of areas with high concentrations and to verify their impact on the observation data and on the simulation. The main area with high concentrations was near the coast (red circle) where the contribution of all biogeochemical variables was clearly important (chlorophyll, particulate organic carbonate and microzooplankton).

Similar structures can be observed between the SeaWiFS observations and the simulation (in the red circle for example). Qualitatively, the radiances are consistent with the modeled surface variables. Indeed, high values of radiance in the observation data correspond to high values in the simulation. Furthermore, the areas of high values of radiance correspond to areas of high concentrations detected in areas near the coast, shown in Fig. 6.

However, the values of the water-leaving radiances are not directly comparable. Indeed, angular information (view and solar) were not completely taken into account. This may explain some of the quantitative differences obtained. This hypothesis was examined in the second simulation, over Pagasitikos Gulf.

\subsection{Second evaluation: Pagasitikos Gulf}

Additional to the inclusion of full angular information, further interest for this test case was to demonstrate the importance of all the biogeochemical variables (not only chlorophyll but also non-algal particulate matter) and the impact of the vertical structure (concentrations profiles). In these simulations, the depth Zmax considered for the ecological concentrations varied $(10 \mathrm{~m}, 20 \mathrm{~m}, 30 \mathrm{~m}$, and $40 \mathrm{~m})$ in order to visualize the corresponding variations of the water-leaving radiances. Therefore, the water column considered for each value of Zmax was not the same : the IOPs below Zmax have been forced to their value at Zmax, and thus varied as a function of the concentration profiles considered from the model. This sensitivity study allowed the analysis of the impact of vertical structures of biogeochemical variable concentrations on the modeled water-leaving radiances.

Visualization of vertical structures of the model variables is of particular interest for this analysis. Figs. 7 and 8 present the variations of the modeled concentrations profiles (respectively chlorophyll and non-algal suspended particular matter) between the sea surface and different depths. These variations are estimated by subtracting the 

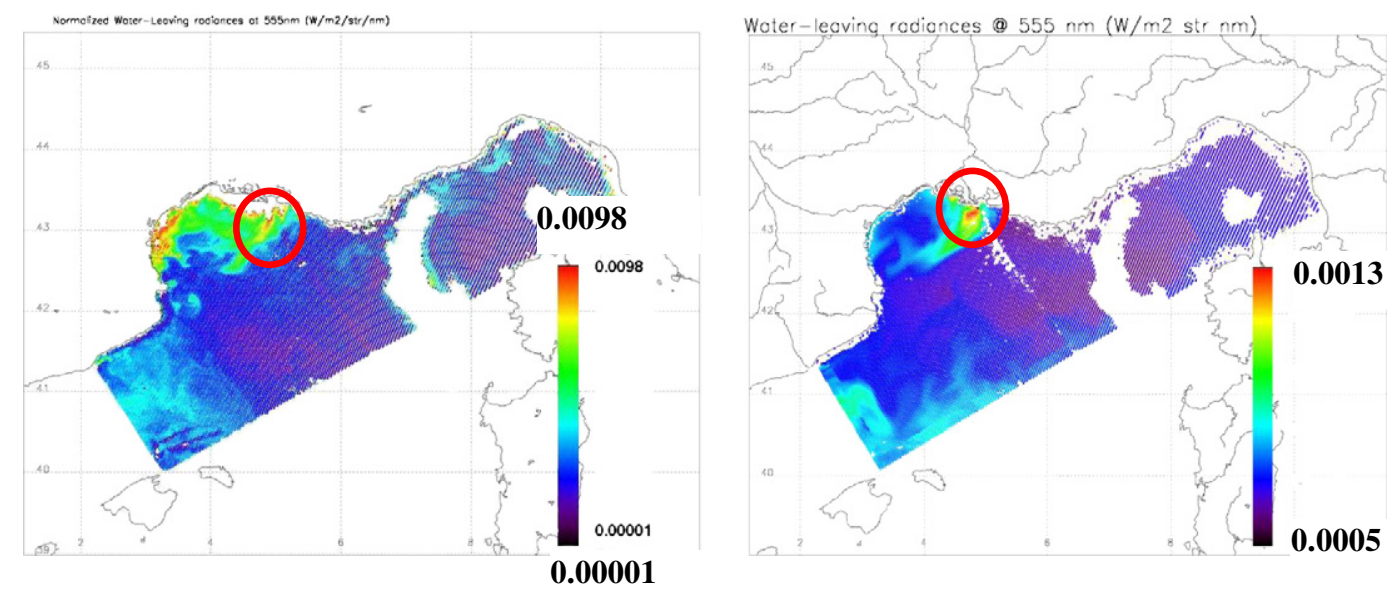

Observed water-leaving radiance $\left(\mathrm{W} / \mathrm{m}^{2} / \mathbf{n m} / \mathbf{s r}\right)$

Synthetic water-leaving radiance $\left(\mathrm{W} / \mathrm{m}^{2} / \mathrm{sr} / \mathrm{nm}\right)$, depth $=10 \mathrm{~m}$

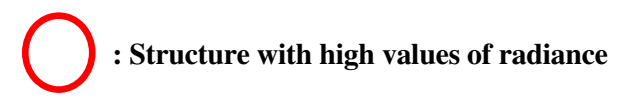

Fig. 6. Observed and synthetic water-leaving radiance at $555 \mathrm{~nm}$ on the observation points (SeaWiFS, 09 February 2004). Observed water-leaving radiance (W/ $\mathrm{m}^{2} / \mathrm{nm} / \mathrm{sr}$ ). Synthetic water-leaving radiance $\left(\mathrm{W} / \mathrm{m}^{2} / \mathrm{sr} / \mathrm{nm}\right)$, depth $=10 \mathrm{~m}$ : Structure with high values of radiance.

concentrations at different depths $z$ (from $z=5 \mathrm{~m}$ to $z=50 \mathrm{~m}$ ) from the concentrations at the surface.

For Pagasitikos Gulf, the biogeochemical variable concentrations were maximal around $35 \mathrm{~m}$ depth whereas for the Gulf of Lion they were maximal near the sea surface. Fig. 9 presents the observed water-leaving radiances as provided by MODIS at $412 \mathrm{~nm}$.
Fig. 10 presents the same synthetic quantities as simulated from the model variables and the observation operator. The simulations worked for different maximal depths where the model concentrations are taken into account for computing the IOPs (cf. Figs. 7 and 8): from $10 \mathrm{~m}$ to $40 \mathrm{~m}$. Below these Zmax values, the water is assumed as homogeneous and infinitely deep and the IOPs are taken
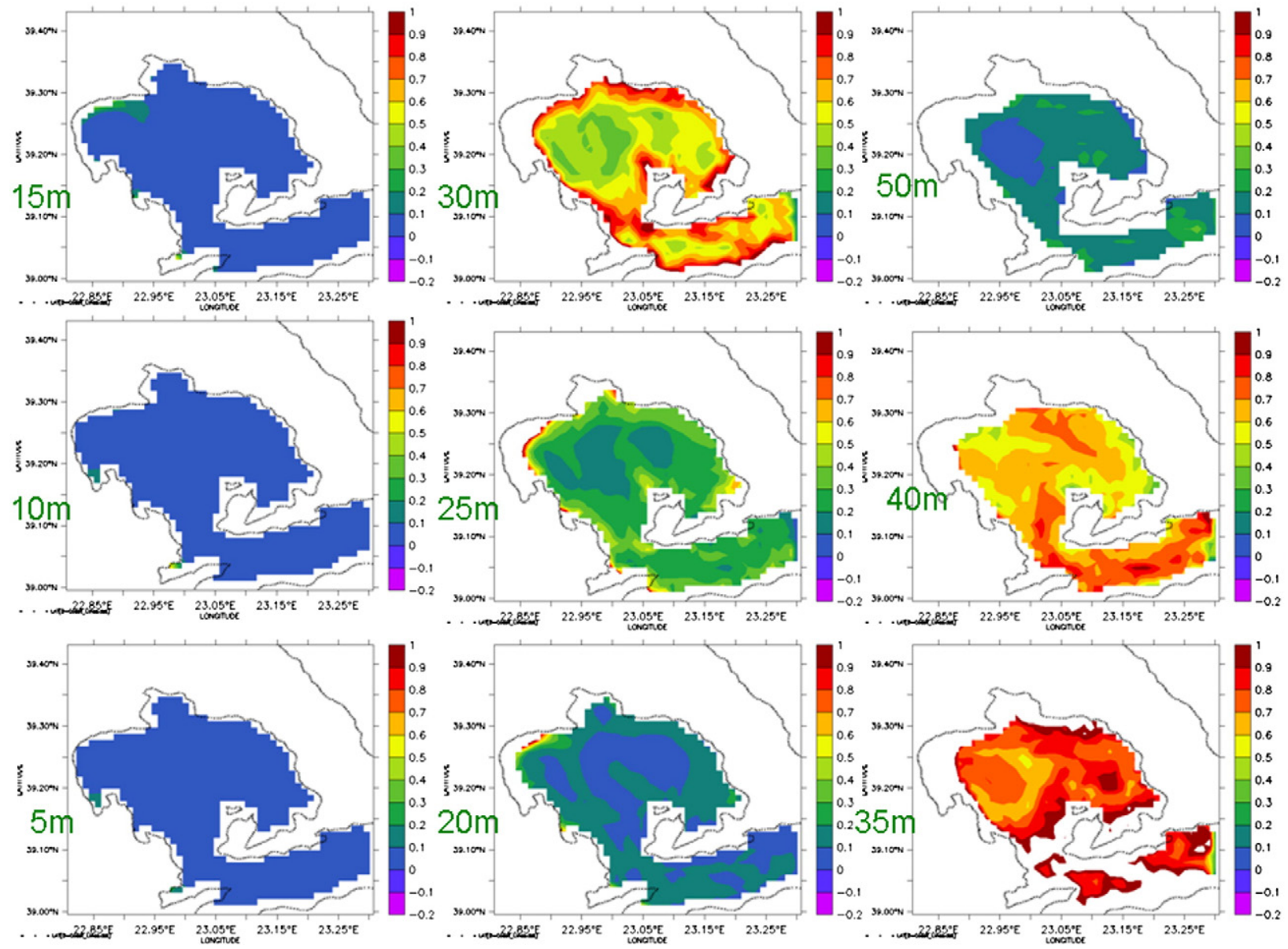

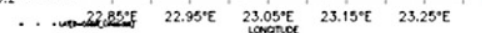

Fig. 7. Variations of chlorophyll concentrations from ERSEM model data, 18 August 2003 (subtraction between the concentrations at the surface and the different depths Zi). 

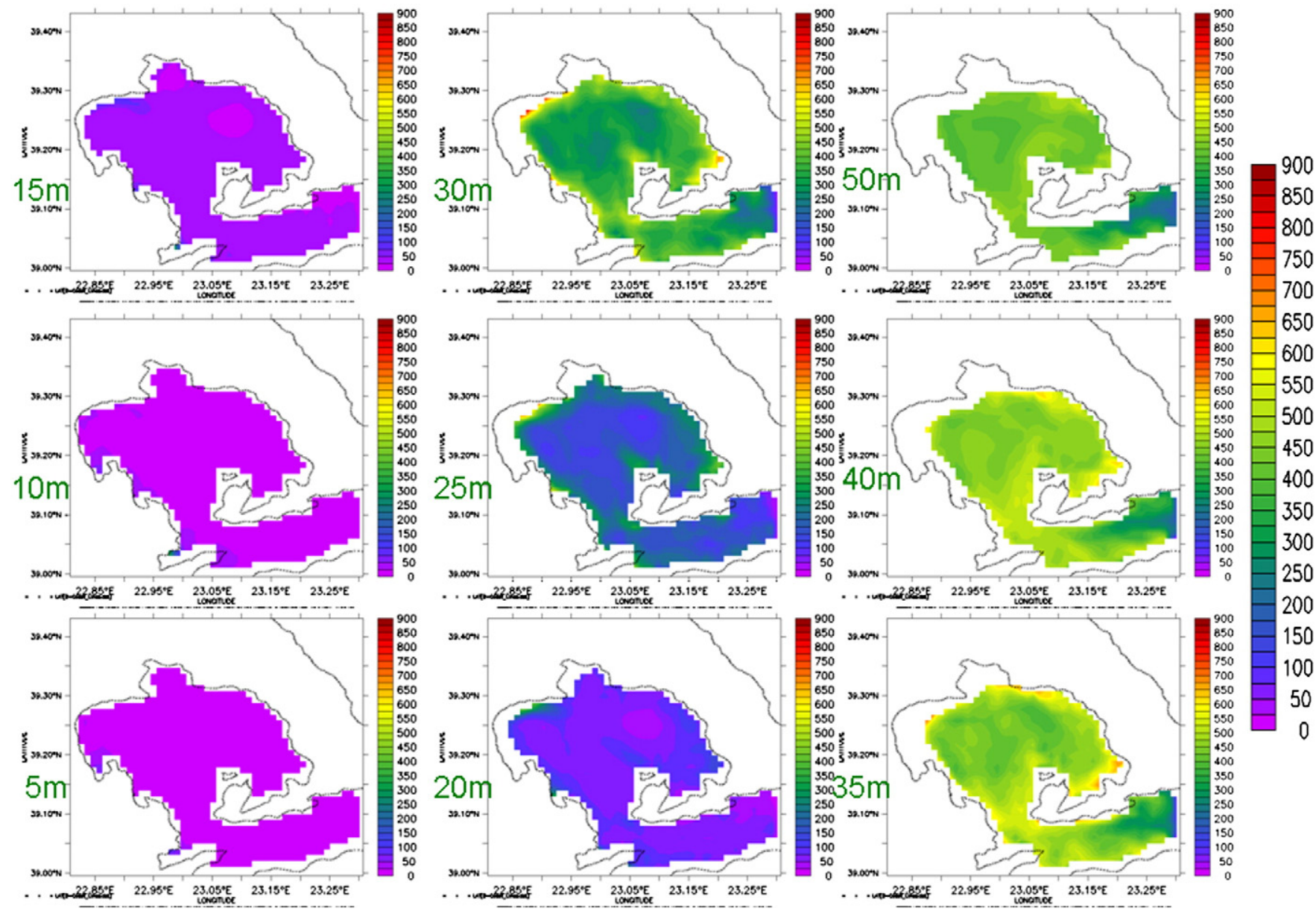

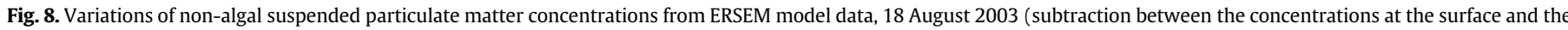
different depths $\mathrm{Zi}$ ).

equal to the values at depth Zmax. Regarding the variations of Zmax considered, the synthetic water-leaving radiances increase first from $10 \mathrm{~m}$ to $20 \mathrm{~m}$ and then decrease, from $30 \mathrm{~m}$. Similarly, the biogeochemical concentrations increase up to $35 \mathrm{~m}$. It is clear that there is a link between both of these increases. Indeed, large values of biogeochemical concentrations involve important IOPs of the water column.

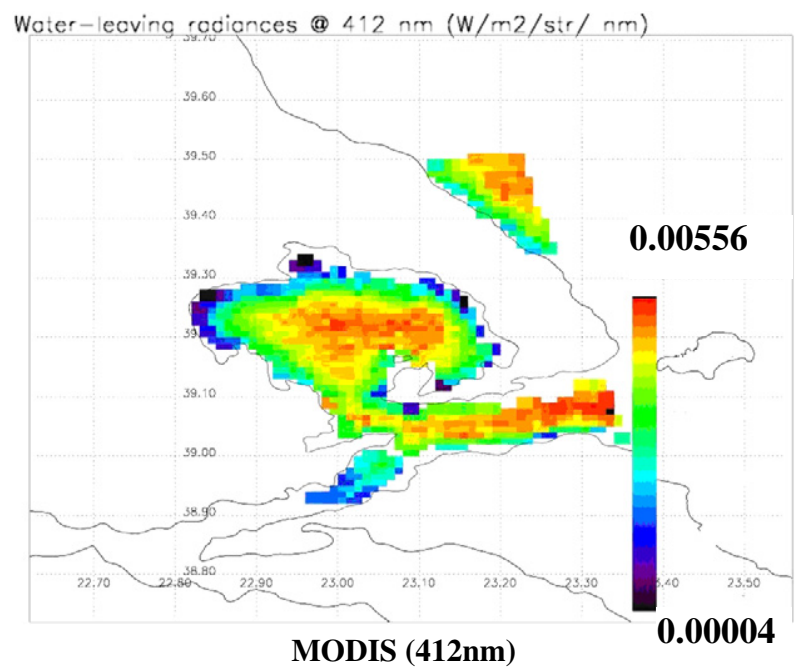

Fig. 9. Observed water-leaving radiance (W/ $\left./ \mathrm{m}^{2} / \mathrm{nm} / \mathrm{sr}\right), 18$ August 2003.
Again, this preliminary analysis is limited because of differences in magnitude and structure between observed and simulated radiances. Nevertheless, the following points can be stated:

- First, the vertical trends shown in Fig. 10 clearly indicate that in this case the radiances are sensitive to the sub-surface structure of the biogeochemical variables. The remotely sensed observation thus contains information on the concentration profiles, and cannot be related only to the chlorophyll at the surface. This is in concordance with recent work in case-I waters where the impact of the vertical structure of chlorophyll on the remotely sensed signal has also been noted (Charria et al., 2003; Da Silva et al., 2002).

- Second, the - even qualitative - comparison between Figs. 9 and 10 indicates that considering a simulation only in the first $10 \mathrm{~m}$ of the water column is not sufficient to capture the main structures of the signal. The high-value structures, which are qualitatively comparable in observation and simulations, are detected only by considering depths below $20 \mathrm{~m}$.

Therefore, the simulations with a Zmax as large as possible seem more realistic than simulations taking into account only the surface concentrations. However, large differences persist in both cases between simulations and observation, avoiding a more quantitative discussion at this stage. Additional sensitivity studies should be performed in order to distinguish between approximations in the observation operator which have to be improved, and the necessary improvement of modeled structures and concentrations. In particular, the effects of a more realistic instrument response function, of a careful consideration of all 

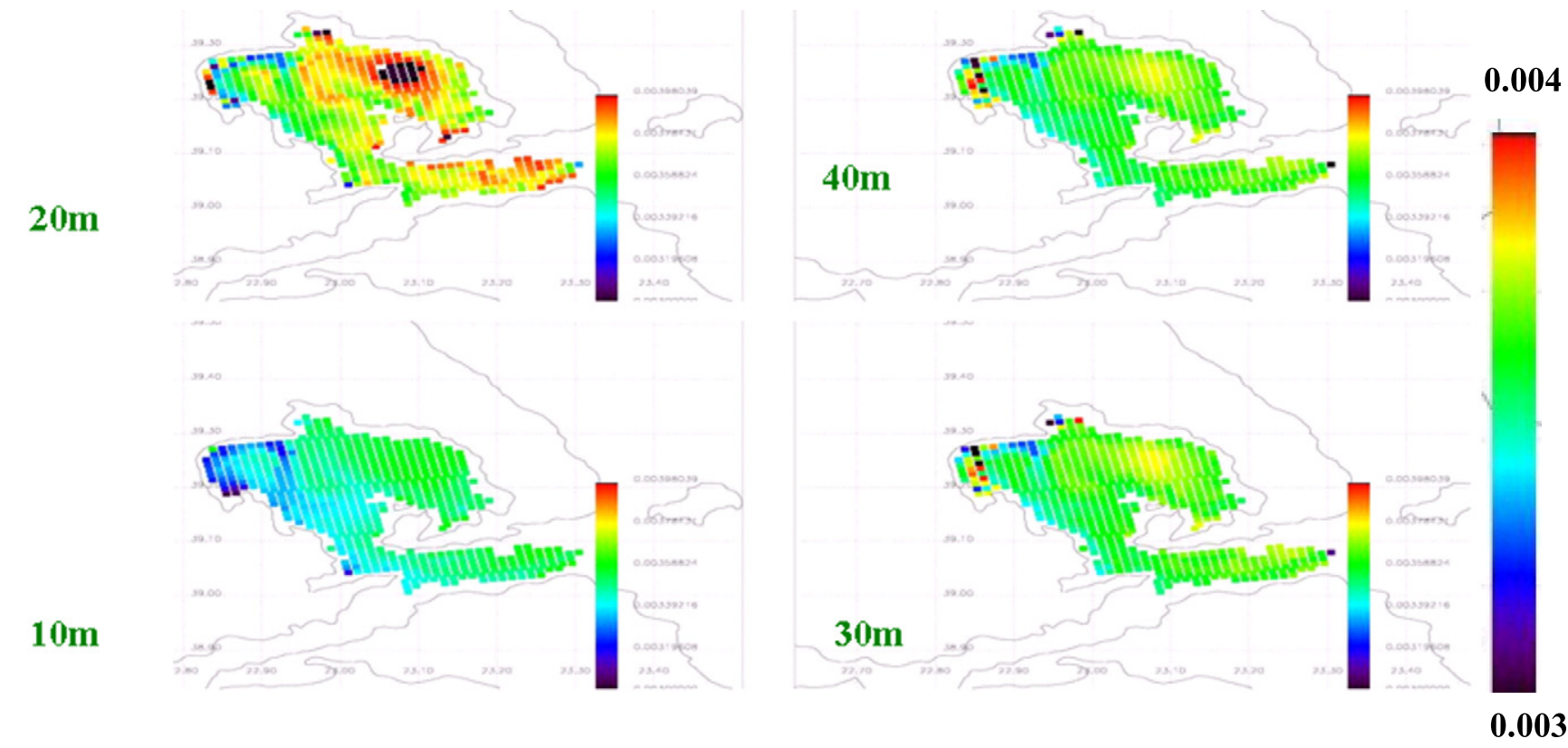

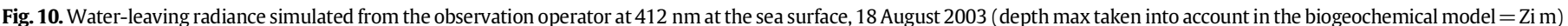
$\left(\mathrm{W} / \mathrm{m}^{2} / \mathrm{nm} / \mathrm{sr}\right)$.

observation angles, of the wind-blown surface, should all be assessed. Furthermore, it is evident from the results that additional sensitivity tests are required to quantify the relative separate contributions of biogeochemical variables (e.g. chlorophyll vs microzooplankton) to the water leaving radiance, rather than just highlighting them as is the case with these initial results. From the modeling point of view, a better representation of CDOM and a proper consideration of realistic water bottom reflectance could be a prerequisite for a quantitative use of the remote sensing observation.

\section{Conclusions}

A demonstration 'observation operator' system has been developed, that is based on biogeochemical model output, optical properties (apparent and inherent), and radiative transfer modeling, in order to map the bio-geochemical variables into water-leaving radiances that can be observed from remote sensing instruments. In the forward mode we tested the system by producing SeaWIFS and MODIS synthetic images of the water leaving radiance for the coastal test sites of INSEA.

A preliminary, qualitative comparison of these synthetic images with similar observed quantities was carried out in order to establish the potential of this approach for the better use of ocean color satellite data. From a qualitative analysis, initial indications are that the observation operator approach has the potential to allow consistent mapping of model variables into observed quantities. The potential gain of this approach, which can simplify the transport of measurement errors and reduce the need for approximations inherent in previous approaches, has been highlighted. In particular, the results obtained for the Gulf of Lion and Pagasitikos Gulf indicate that all the ecological variables, as well chlorophyll or non-algal particulate matter, are important to justify and explain the structures observed in the simulations. Furthermore, sensitivity tests in Pagasitikos Gulf clearly demonstrate the importance of considering sub-surface concentrations and vertical profiles of biogeochemical variables in the computation of synthetic images, and give some evidence of the capability for space measurements to derive vertical information.

However, this preliminary analysis remains limited to qualitative discussions, and additional sensitivity studies, as well as refinements of the observation operator hypotheses, are required for a quantitative demonstration of the first interest of this approach, i.e. to validate the quality of remote sensing data in coastal areas for use in eutrophication assessment and the validation of ecological modeling.

Key aspects of the forward modeling of radiances to be tested and consolidated for a quantitative use of the operator have been identified at the end of Section 3. These points will be addressed to reach a quantitative validation of the observation operator approach through direct comparison of simulated and observed radiances on the INSEA sites. In addition to the key points listed in Section 3, the effect of the atmosphere on the observed water-leaving radiance product should also be carefully considered.

The above quantitative assessment of the observation operator approach shall be considered as the necessary preliminary step for a consistent and optimal exploitation of satellite data in eutrophic coastal waters. This is the basis for the further development of approaches able to effectively use remotely sensed information. Thus, two complementary approaches are proposed based on the methodological developments presented in this paper and the INSEA project for further studies related to remotely sensed data: satellite retrieval based on optimal inversion; and direct assimilation of satellite data into ecological models.

First, optimal inversion experiments controlled by the models shall be developed for retrieving remote-sensed chlorophyll products consistent with in situ measurements at INSEA sites. Satellite retrievals and data assimilation in ecological models are very similar mathematical inverse problems that can be jointly solved with benefits, provided that the observation operator associated with the simulation of satellite data from ecological model variables is accurate enough. When merging the inversion of the satellite data into the assimilation scheme, one profits from the information already available by means of the ecological model with its associated error. The background information derived from the model is expected to be much closer to the real bio-geochemical state than any other database or empirical parameterization usually used in retrieval algorithms. The development of an optimal inversion scheme based on the use of the observation operator is thus a consistent way for exploiting both information from the model and from the observation. A scheme based on variational principles, applied to the analysis of the variations of radiance with respect to biogeochemical variables computed from the observation operator, should be able to consistently extract 
useful information from remotely sensed radiance based on a first guess solution provided by the model and its error. Such a scheme will be tested on the INSEA sites.

Second, the development of operational scenarios to properly integrate remote sensing data in the model-based management tools of coastal zones shall consider the direct assimilation of the satellite radiances or water-leaving reflectances rather than bio geochemical products retrieved from empirical algorithms. Numerical Weather Prediction (NWP) assimilation gives historical experience of satellite data that were first inverted to retrieve model variables and then assimilated in NWP systems. This results in high-quality satellite radiance measurements being treated as poor-quality atmospheric radiosondes, which led to a negative impact on NWP systems (Pailleux, 1990). In cases where an accurate and efficient observation operator is available, the direct use of satellite radiance is the more efficient way - and sometimes the only way - for the proper use of space-based information. Based on a consolidated validation of the observation operator approach for coastal waters, such operational scenarios will be explored.

Because the observation operator allows the understanding of the processes governing the information captured by the data, an operational use of this software could be very fruitful for coastal water management systems. The advantage of this operator is to be a good compromise between a simple use of the remotely sensed information and their routine implementation within operational coastal management systems, and thus a useful tool to explore potentialities of remote sensing and prepare its consistent use. Global coverage and consistency of satellite products allow generalizing the management systems to different regions and ecosystems.

\section{Acknowledgments}

The research presented in this paper was supported by the European Union FP 6 projects INSEA (Data Integration System for Eutrophication Assessment in Coastal Waters) and SESAME (Southern European Seas: Assessing and Modeling Ecosystem Changes). The authors would also like to thank the NASA Ocean Biology Processing Group at the Goddard Space Flight Center for the production and distribution of the ocean color data, Dr. Curtis D. Mobley of the University of Washington and Sequoia Scientific Inc. for the use of the HYDROLIGHT model and two anonymous reviewers for their constructive remarks which helped to improve the paper.

\section{References}

Anderson, T.R., Pondaven, P., 2003. Non-redfield carbon and nitrogen cycling in the Sargasso Sea: pelagic imbalances and export flux. Deep Sea Research Part I 50, 573-591.

Arrigo, K.R., van Dijken, G.L., 2004. Annual changes in sea-ice, chlorophyll $a$, and primary production in the Ross Sea, Antarctica. Deep Sea Research Part II 51, 117-138.

Bailey, S.W., Werdell, P.J., 2006. A multi-sensor approach for the on-orbit validation of ocean color satellite data products. Remote Sensing of Environment 102, 12-23.

Bailey, S.W., McClain, C.R., Werdell, P.J., Schrieber, B.D., 2000. Normalized waterleaving radiance and chlorophyll-a match-up analyses. In: Hooker, S.B., Firestone, E.R. (Eds.), 2000. SeaWiFS Postlaunch Technical Report Series 10, SeaWiFS Postlaunch Calibration and Validation Analyses, Part 2. NASA Tech. Memo. 2000-206892, 10 (Greenbelt, MD, NASA Goddard Space Flight Center, USA).

Baklouti, M., Diaz, F., Pinazo, C., Faure, V., Quéguiner, B., 2006a. Investigation of mechanistic formulations depicting phytoplankton dynamics for models of marine pelagic ecosystems and description of a new model. Progress in Oceanography 71, $1-33$.

Baklouti, M., Faure, V., Pawlowski, L., Sciandra, A., 2006b. Investigation and sensitivity analysis of a mechanistic phytoplankton model implemented in a new modular numerical tool (Eco3M) dedicated to biogeochemical modelling. Progress in Oceanography $71,34-58$

Baretta, J.W., Ebenhoeh, W., Ruardij, P., 1995. The European Regional Seas Ecosystem Model, a complex marine ecosystem model. Netherlands Journal of Sea Research $33,233-246$.

Blumberg, A., Mellor, G.L., 1987. A description of a three-dimensional coastal ocean circulation model, In Three-Dimensional Coastal Ocean Models. In: Heaps, N.S. (Ed.), American Geophysical Union, Washington, DC, pp. 1-16.
Bricaud, A., Babin, M., Morel, A., Claustre, H., 1995. Variability in the chlorophyllspecific absorption coefficients of natural phytoplankton: analysis and parameterization. Journal of Geophysical Research 100 (C7), 13321-13332.

Bricaud, A., Morel, A., Babin, M., Allali, K., Claustre, H., 1998. Variations of light absorption by suspended particles with the chlorophyll a concentration in oceanic (Case 1) waters: analysis and implications for bio-optical models. Journal of Geophysical Research 103, 31,033-31,044.

Bricaud, A., Bosc, E., Antoine, D., 2002. Algal biomass and sea surface temperature in the Mediterranean Basin: intercomparison of data from various satellite sensors, and implications for primary production estimates. Remote Sensing of Environment 81, 163-178.

Carmillet, V., Brankart, J.-M., Brasseur, P., Drange, H., Evensen, G., Verron, J., 2001. A singular evolutive extended Kalman filter to assimilate ocean color data in a coupled physicalbiochemical model of the North Atlantic ocean. Ocean Modelling 3, 167-192.

Charria, G., Melin, F., Dadou, I., Radenac, M.-H., Garcon, V., 2003. Rossby wave and ocean color: the cells uplifting hypothesis in the South Atlantic Subtropical Convergence Zone. Geophysical Research Letters 30 (3), 1125.

Cloern, J.E., 2001. Our evolving conceptual model of the coastal eutrophication problem. Marine Ecology Progress Series 210, 223-253.

Da Silva, J.C.B., New, A.L., Srokosz, M.A., Smith, T.J., 2002. On the observability of internal tidal waves in remotely-sensed ocean colour data. Geophysical Research Letters 29 (12), 1569.

Darecki, M., Kaczmarek, S., Olszewski, J., 2005. SeaWiFS ocean colour chlorophyll algorithms for the southern Baltic Sea. International Journal of Remote Sensing 26, 247-260.

Defoin-Platel, M., Chami, M., 2007. How ambiguous is the inverse problem of ocean color in coastal waters. Journal of Geophysical Research 112 (C03004).

Durrieu de Madron, X., Denis, L., Diaz, F., Garcia, N., Guieu, C., Grenz, C., Loÿe-Pilot, M.-D., Ludwig, W., Moutin, T., Raimbault, P., Ridame, C., 2003. Nutrients and carbon budgets for the Gulf of Lion during the Moogli cruises. Oceanologica Acta 26 (4), 421-433.

EEA, 2000. Environmental Signals 2000 (European Environment Agency, Environmental assessment report No. 6.).

EEA, 2001. Eutrophication in Europe's Coastal Waters (European Environment Agency, Environmental Assessment Series No. 7).

ERM, 2000. Criteria for the Definition of Eutrophication in Marine/Coastal Waters. Final Report of European Commission Contract number B4-3040/98/000705/MAR/D1.

ERSEM-I, 1995. European regional seas ecosystem model I (1990-1993) Netherlands Journal of Sea Research 33, 3-4 (special issue).

European regional seas ecosystem model II (1993-1996) Journal of Sea Research 38 3-4 (special issue).

Estournel, C., Broche, P., Marsaleix, P., Devenon, J.L., Auclair, F., Vehil, R., 2001. The Rhone River plume in unsteady conditions: numerical and experimental results. Estuarine, Coastal and Shelf Science 53, 25-38.

Estournel, C., Durrieu de Madron, X., Marsaleix, P., Auclair, F., Julliand, C., Vehil, R., 2003. Observation and modeling of the winter coastal oceanic circulation in the Gulf of Lion under wind conditions influenced by the continental orography (FETCH experiment) Journal of Geophysical Research 108 (C3), 8059.

Estournel, C., Auclair, F., Lux, M., Nguyen, C., Marsaleix, P., 2007. "Scale oriented" embedded modeling of the north-western Mediterranean in the frame of MFSTEP. Ocean Science Discussions 4, 145-187.

Eyre, J.R., 1989. Inversion of cloudy satellite sounding radiances by nonlinear optimal estimation. I: Theory and simulation for TOVS. The Quarterly Journal of the Royal Meteorological Society 115, 1001-1026.

Eyre, J.R., Kelly, A., McNally, A.P., Anderson, E., Persson, A., 1993. Assimilation of TOVS radiance information through one-dimensional variational analysis. The Quarterly Journal of the Royal Meteorological Society 119, 1427-1463.

Garcia, C.A.E., Garcia, V.M.T., McClain, C.R., 2005. Evaluation of SeaWiFS chlorophyll algorithms in the southwestern Atlantic and Southern Oceans. Remote Sensing of Environment 95, 125-137.

Garcia, V.M.T., Signorini, S., Garcia, C.A.E., McClain, C., 2006. Empirical and semianalytical chlorophyll algorithms in the southwestern Atlantic coastal region $\left(25-40^{\circ} \mathrm{S}\right.$ and $\left.60-45^{\circ} \mathrm{W}\right)$. International Journal of Remote Sensing $27,1539-1562$.

Geernaert, G.L., 1990. Bulk parameterizations for the wind stress and heat fluxes. In: Geernaert, G.L., Plant, W.J. (Eds.), Surface Waves and Fluxes, vol. I, Current Theory. Springer, New York, pp. 91-172.

Gordon, H.R Clark, D.K, Brown, JW. Brown, O.B, Evans, R.H. Broenkow, W.W 1983. Phytoplankton pigment concentrations in the Middle Atlantic Bight: comparison of ship determinations and CZCS estimates. Applied Optics 22, 20-36.

Gregg, W.W., Carder, K.L., 1990. A simple spectral solar irradiance model for cloudless maritime atmospheres. Limnology and Oceanography 35 (8), 1657.

Gregg, W.W., Casey, N.W., 2004. Global and regional evaluation of the SeaWiFS chlorophyll data set. Remote Sensing of Environment 93, 463-479.

Herrmann, M.J., Somot, S., Sevault, F., Estournel, C., Deque, M., 2008. Modeling the deep convection in the northwestern Mediterranean Sea using an eddy-permitting and an eddy-resolving model: case study of winter 1986-1987. Journal of Geophysical Research 113, C04011.

Hooker, S.B., McClain, C.R., 2000. The calibration and validation of SeaWiFS data. Progress in Oceanography 45, 427-465.

Ide, K., Courtier, P., Ghil, M., Lorenc, A.C., 1997. Unified notation for data assimilation: operational, sequential and variational. Journal of the Meteorological Society of Japan 75 (1B), 181-189 Special issue on data assimilation in meteorology and oceanography: theory and practice.

IOCCG, 2000. Report Number 3: Remote Sensing of Ocean Colour in Coastal, and Other Optically-Complex, Waters. International Ocean Colour Coodinating Group, Dartmouth, Canada.

IOCCG, 2006. Report Number 5: Remote Sensing of Inherent Optical Properties: Fundamentals, Tests of Algorithms and Applications. International Ocean Colour Coodinating Group, Dartmouth, Canada. 
Korres, G., Lascaratos, A., Hatziapostolou, E., Katsafados, P., 2002. Towards an ocean forecasting system for the Aegean Sea. The Global Atmosphere and Ocean System 8, 191-218.

Korres, G., Triantafyllou, G., Petihakis, G., Raitsos, D., Hoteit, I., Pollani, A., Colella, S. Tsiaras, K., 2012. A data assimilation tool for the Pagasitikos Gulf ecosystem dynamics: methods and benefits. Journal of Marine Systems 94, S102-S117 (this issue).

Le Quéré, C., Harrison, S., Prentice, I.C., Buitenhuis, E.T., Aumont, O., Bopp, L., Claustre, H., Cotrim Da Cunha, L., Geider, R., Giraud, X., Klass, C., Kohfeld, K.E., Legendre, L., Manizza, M., Platt, T., Rivkin, R.B., Sathyendranath, S., Uitz, J., Watson, A.J., WolfGladrow, D., 2005. Ecosystem dynamics based on plankton functional types for global ocean biogeochemistry models. Global Changes Biology 11, 2016-2040.

Lin, H.J., Nixon, S.W., Taylor, D.I., Granger, S.L., Buckley, B.A., 1996. Responses of epiphytes on eelgrass, Zostera marina L., to separate and combined nitrogen and phosphorus enrichment. Aquatic Botany 52, 243-258.

Lorenc, A.C., 1986. Analysis methods for numerical weather prediction. The Quarterly Journal of the Royal Meteorological Society 112, 1177-1194.

Madec, G., Delecluse, P., Imbard, M., Levy, C., 1997. OPA Release 8, Ocean General Circulation Model Reference Manual. Laboratoire d'Océanographie Dynamique et de Climatologie/ Institut Pierre Simon Leplace, France.

Marrari, M., Hu, C., Daly, K., 2006. Validation of SeaWiFS chlorophyll a concentrations in the Southern Ocean: a revisit. Remote Sensing of Environment 105, 367-375.

Marsaleix, P., Auclair, F., Floor, J.W., Herrmann, M.J., Estournel, C., Pairaud, I., Ulses, C., 2008. Energy conservation issues in sigmacoordinate free-surface ocean models. Ocean Modelling 20, 61-89.

McClain, C.R., 2009. A decade of satellite ocean color observations. Annual Review of Marine Science 1, 19-42.

McClain, C.R., Carder, K.L., Muller-Karger, F., Harding, L, Magnuson, A., Phynney, D., Moore G.F., Aiken, J., Arrigo, K., Letelier, R., Culver, M., 2000. Ocean color chlorophyll a algorithm for SeaWiFS, OC2, and OC4: version 4. In: Hooker, S.B., Firestone, E.R. (Eds.), SeaWiFS Postlaunch Calibration and Validation Analyses, Part 3. NASA Tech. Memo., 11. NASA Goddard Space Flight Center, Greenbelt, MD, pp. 9-23. 206892.

Mellor, G.L., 1991. An eqaution of state for numerical models of oceans and estuaries. Journal of Atmospheric and Oceanic Technology 8, 609-611.

Mitchell, B.G., 1994. Coastal zone color scanner retrospective. Journal of Geophysical Research 99, 7291-7292.

Mitchell, B.G., Holm-Hansen, O., 1991. Bio-optical properties of Antarctic Peninsula waters: differentiation from temperate ocean models. Deep Sea Research 38, 1009-1028.

Mobley, C.D., 1994. Light and Water: Radiative Transfer in Natural Waters. Academic Press, New York.

Mobley, C.D., Sundman, L.K., 2006. HYDROLIGHT 4.3. Technical Documentation. Sequoia Scientific Inc., Bellevue, USA.

Moore, J.K., Abbott, M.R, Richman, J.G., Smith, W.O Cowles, TJ. Coale, K.H. Gardner, W.D., Barberet, R.T., 1999. SeaWiFS satellite ocean color data from the Southern Ocean. Geophysical Research Letters 26 (10), 1465-1468.

Morel, A., 1988. Optical modeling of the upper ocean in relation to its biogenous matter content (case I waters) Journal of Geophysical Research 93 (C9) 10749-10768.

Morel, A., Antoine, D., 2007. ATBD 2.9: Pigment Index Retrieval in Case 1 Waters (ESA Nordwijk, The Netherlands, ESA Doc. no. PO-TN-MEL-GS-0005)Available online at http://envisat.esa.int/instruments/meris/pdf/atbd_2_09.pdf.

Morel, A., Prieur, L., 1977. Analysis of variations in ocean colour. Limnology and Oceanography 22, 709-722.

Moutin, T., Raimbault, P., Golterman, H.L., Coste, B., 1998. The input of nutrients by the Rhone River into the Mediterranean Sea: recent observations and comparison with earlier data. Hydrobiologia 374, 237-246.

Nixon, S.W., 1995. Coastal marine eutrophication: a definition, social causes and future concerns. Ophelia 41, 199-219.

O'Reilly, J.E., Maritorena, S., Mitchell, B.G., Siegel, D.A., Carder, K.L., Garver, S.A., Kahru, M., McClain, C.R. 1998. Ocean color chlorophyll algorithms for SeaWiFS. Journal of Geophysical Research 103, 24937-24953.
O'Reilly, J.E., Maritorena, S., Siegel, D.A., O'Brien, M.C., Toole, D., Mitchell, B.G., Kahru, M., Chavez, F.P., Strutton, P., Cota, G.F., Hooker, S.B., McClain, C.R., Carder, K.L., Muller-Karger, F., Harding, L., Magnuson, A., Phinney, D., Moore, G.F., Aiken, J., Arrigo, K.R., Letelier, R., Culver, M., 2000. NASA Tech. Memo. 2000-206892: Ocean Color Chlorophyll a Algorithms for SeaWiFS, OC2, OC4: Version 4, pp. 9-23. NASA Goddard Space Flight Center, Greenbelt, USA.

Pailleux, J., 1990. A global variational assimilation scheme and its application for using TOVS radiances. Proceedings of the WMO International Symposium on Assimilation of Observations in Meteorology and Oceanography, Clermont-Ferrand, France, pp. 325-328.

Petihakis, G., Triantafyllou, G., Theodorou, A., 2000. A numerical approach to simulate nutrient dynamics and primary production of a semi-enclosed coastal ecosystem (Pagasitikos Gulf, Western Aegean, Greece) Periodicum Biologorum 102 (1), 339-348.

Petihakis, G., Triantafyllou, G., Allen, I.J., Hoteit, I., Dounas, C., 2002. Modelling the spatial and temporal variability of the Cretan Sea ecosystem. Journal of Marine Systems 36, 173-196.

Prieur, L., Sathyendranath, S., 1981. An optical classification of coastal and oceanic waters based on the specific spectral absorption curves of phytoplankton pigments, dissolved organic matter, and other particulate materials. Limnology and Oceanography 26 (4), 671-689.

Prunet, P., Thépaut, J.-N., Cassé, V., Pailleux, J., Baverez, A., Cardinali, C., 2000. Strategies for the assimilation of new satellite measurements at Météo-France. Advances in Space Research 25 (5), 1073-1076.

Raick, C., Delhez, E.J.M., Soetaert, K., Grégoire, M., 2005. Study of the seasonal cycle of the biogeochemical processes in the Ligurian Sea using a 1D interdisciplinary model. Journal of Marine Systems 55, 177-203.

Richtmyer, R.D., Morton, K.W., 1994. Difference Methods for Initial-Value Problems. Krieger Publishing, Malabar, Florida, U.S.

Rodgers, C.D., 2000. Inverse Methods for Atmospheric Sounding: Theory and Practice. World Scientific Publishing Company, Singapore.

Sancak, S., Besiktepe, S.T., Yilmaz, A., Lee, M., Frouin, R., 2005. Evaluation of SeaWiFS chlorophyll-a in the Black and Mediterranean Seas. International Journal of Remote Sensing 26 (10), 2045-2060.

Sathyendranath, S., Prieur, L., 1981. A model of diffuse reflectance and its remote sensing applications, with special reference to coastal ("case 2") waters. In A Collection of Extended Abstracts of Papers Presented at the Symposium on the Radiation Transfer in the Oceans and Remote Sensing of Ocean Properties, IAMAP Third Scientific Assembly, Hamburg, August 1981, pp 83-85. IAMAP, Boulder, Colorado, USA.

Sathyendranath, S., Prieur, L., Morel, A., 1989. A three-component model of ocean colour and its application to remote sensing of phytoplankton pigments in coastal waters. International Journal of Remote Sensing 10 (8), 1373-1394.

Sempéré, R., Charrière, B., van Wambeke, F., Cauwet, G., 2000. Carbon inputs of the Rhone River to the Mediterranean Sea: biogeochemical implications. Global Biogeochemical Cycles 14 (2), 669-681.

Soetaert, K., de Clippele, V., Herman, P.M.J., van Oevelen, J., 2003. A Flexible Environment for Mathematically Modelling the Environment (Manual), NIOO-CEMO. Netherlands Institute of Ecology-Centre for Estuarine and Coastal Ecology, Yerseke, The Netherlands.

Triantafyllou, G., Korres, G., Hoteit, I., Petihakis, G., Banks, A.C., 2007. Assimilation of ocean colour data into a biogeochemical flux model of the eastern Mediterranean Sea. Ocean Science 3 (3), 397-410.

Ulses, C., Estournel, C., Bonnin, J., Durrieu de Madron, X., Marsaleix, P., 2008. Impact of storms and dense water cascading on shelf-slope exchanges in the Gulf of Lion (NW Mediterranean). Journal of Geophysical Research 113, C02010.

Volpe, G., Santoleri, R., Vellucci, V., Ribera d'Alcalà, M., Marullo, S., D'Ortenzio, F., 2007. The colour of the Mediterranean Sea: global versus regional bio-optical algorithms evaluation and implication for satellite chlorophyll estimates. Remote Sensing of Environment 107, 625-638.

Werdell, J., 2009. Global bio-optical algorithms for ocean color satellite applications. Eos 90 (1), 4

WHO, 2002. Eutrophication and Health. European Commission Office for Official Publications of the European Communities, Luxembourg. 